\title{
First record of the genus Azadinium (Dinophyceae) from the Shetland Islands, including the description of Azadinium polongum sp. nov.
}

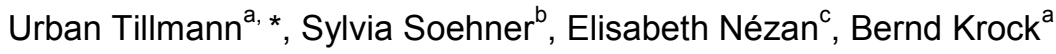

\begin{abstract}
${ }^{a}$ Alfred Wegener Institute, Am Handelshafen 12, D-27570 Bremerhaven, Germany
b Department Biologie I, Systematische Botanik und Mykologie, Ludwig-Maximilians-Universität München, D80638 München, Germany

c IFREMER, Laboratoire Environnement et Ressources Finistère-Bretagne Nord, Station de Biologie Marine, Place de la Croix, BP 40537, 29185 Concarneau Cedex, France
\end{abstract}

*: Corresponding author : Urban Tillmann, Tel.: +49 47148311470 ; fax: +49 47148311425 ;
email address : urban.tillmann@awi.de

\begin{abstract}
:
Azadinium is a dinophycean genus capable of producing azaspiracids (AZAs), a recently discovered group of lipophilic phycotoxins causing human intoxication via mussel consumption. Although initially described from the North Sea, the genus currently consisting of four described species is probably distributed worldwide. Here we report on Azadinium from the Shetland Islands, which are located in the northernmost part of the North Sea and are largely influenced by the Atlantic Ocean. Two strains of Azadinium were isolated from a single water sample. One strain was identified as Azadinium spinosum based on morphology and sequence data and had an AZA cell quota of about $20 \mathrm{fg}$ per cell, similar to all other described strains of the species. The toxin profile consisted of AZA-1 and AZA-2 in a 2.3:1 ratio and a yet undescribed AZA of $715 \mathrm{Da}$. The other strain represents a new species and is here described as Azadinium polongum sp. nov. Like A. spinosum, but different to Azadinium obesum and Azadinium poporum, $A$. polongum has an antapical spine. A. polongum differs from $A$. spinosum by an elongated shape of the pore plate $(\mathrm{Po})$, and X-plate, the location of the ventral pore, and the absence of a distinct pyrenoid with starch sheath. Molecular analysis based on SSU, LSU, and ITS sequencing supported separation of $A$. polongum at the species level. Detailed LC-MS analysis showed that $A$. polongum does not produce any known AZAs in measureable amounts.
\end{abstract}

\section{Highlights}

First record of toxigenic dinophycean genus Azadinium from the Shetland Islands. New isolate of Azadinium spinosum with toxin profile similar to other $A$. spinosum (AZA-1 and -2 and a yet undescribed AZA-716). D Description of a new non-toxigenic species Azadinium polongum sp. nov.

Keywords: Azadinium ; Azaspiracids ; New species ; Shetland Islands 


\section{Introduction}

Public health impairment through consumption of contaminated shellfish is a major problem caused by harmful algal blooms. Among the known responsible compounds, azaspiracids (AZAs) are the most recently discovered group of lipophilic polyether toxins of microalgal origin. After a first poisoning incident in the Netherlands in 1995, azaspiracid toxins were isolated and chemically characterized from Irish shellfish (Satake et al., 1998; Ofuji et al., 1999). Since then, AZA contamination of mussels has been a recurrent and serious problem in Ireland (Salas et al., 2011). In addition, toxins have been observed in samples from Europe, Morocco, Chile, and Japan (Brana Magdalena et al., 2003; Taleb et al., 2006; Amzil et al., 2008; Ueoka et al., 2009; Alvarez et al., 2010; Furey et al., 2010). Although chemistry and toxicity of AZA were intensively studied (Twiner et al., 2008), it took twelve years to discover a planktonic source of the toxin, a small dinophyte (Krock et al., 2009) identified as Azadinium spinosum Elbrächter et Tillmann (Tillmann et al., 2009).

The toxigenic type of this newly erected genus, A. spinosum, was initially isolated off the Scottish east coast, but was subsequently observed and isolated from Denmark (Tillmann et al., 2011) and Irish coastal waters (Salas et al., 2011). The description of A. spinosum was soon followed by both the discovery of new species and new records of Azadinium in natural samples from various areas. First, Azadinium obesum Tillmann et Elbrächter was isolated and described from the same water sample as A. spinosum off Scotland (Tillmann et al., 2010), indicating co-occurrence with the type. Likewise, Azadinium poporum Tillmann et Elbrächter, the third species, was isolated from the same sample as an Danish A. spinosum isolate (Tillmann et al., 2011). Next, Amphidoma caudata Halldal, a species described with the same basic plate pattern as Azadinium (Dodge and Saunders, 1985), was revised both by morphological and molecular data and transferred to the genus as Azadinium caudatum (Haldahl) Nézan et Chomérat (Nézan et al., 2012), with two distinct varieties, var. caudatum 
and var. margalefii. Surprisingly, however, even "true” Amphidoma species and Azadinium turned out to be closely related, despite marked differences in epithecal plate pattern. This was recently shown by morphology and molecular phylogeny for the new species Amphidoma languida Tillmann, Salas et Elbrächter (Tillmann et al., 2012), which was isolated together with an Irish A. spinosum isolate (Salas et al., 2011) and is very similar in general size and shape to species of Azadinium. Both genera Azadinium and Amphidoma are now integrated in the family Amphidomataceae Sournia.

The three available strains of A. spinosum consistently produce AZA with a reported toxin profile consisting of AZA-1 and AZA-2, indicating that the production and profile of known AZAs is a stable characteristic of the species. Other species of Azadinium have initially been reported as non-toxigenic in terms of known AZAs. However, AZA production within Amphidomataceae probably is much more complex and diverse, as recent evidence indicates the presence of new AZAs with a modified substitution pattern in A. poporum and Amphidoma languida (Krock et al., 2012), but toxicity of these compounds still needs to tested.

Although mainly recorded from the North Sea and adjacent areas, species of Azadinium probably have a much wider distribution. Recently, a strain assigned to the genus Azadinium was isolated from coastal waters of Korea (Potvin et al., 2012), which is the first published report of Azadinium from the Pacific Ocean. In terms of morphology, the strain designated as A. cf. poporum by Potvin et al. (2012) is almost identical to the European A. poporum, but differs significantly in terms of sequence data. Recent reports of Azadinium from field samples include blooms in Argentina (Akselman and Negri, 2012), a record from Mexico (Hernandez-Becerril et al., 2010) and an entry in the check list of Black Sea phytoplankton (http://phyto.bss.ibss.org.ua/wiki/Azadinium_spinosum). In addition to these coastal records, specimens of Azadinium were detected in samples collected from the open Indian Ocean (Carbonell-Moore, pers. com.). These records, taken together with the widespread records of 
AZA toxins, indicate a global distribution of Azadinium in general and of the toxigenic $A$. spinosum in particular. Here we report Azadinium from the Shetland Island, expanding the known distribution of the genus to the northernmost part of the North Sea, an area heavily influenced by the Atlantic Ocean. Two cultures were established, one representing the toxinproducing type, $A$. spinosum, and the other representing a new species, $A$. polongum sp. nov.

\section{Material \& Methods}

\subsection{Isolation and culture}

Two isolates of Azadinium, designated as isolate SHETF6 and SHETB2, were established from a water sample collected adjacent to the Shetland Islands $\left(60^{\circ} 12.73^{\prime} \mathrm{N}\right.$ and $\left.0^{\circ} 59.90^{\prime} \mathrm{W}\right)$ during a cruise aboard the research vessel "Heincke” in May 2011. A 1-Liter Niskin bottle sample (10 m depth) was pre-screened (20 $\mu$ m Nitex gauze), gently concentrated by gravity filtration using a 3- $\mu \mathrm{m}$ polycarbonate filter, and examined using an inverted microscope (Axiovert 200M, Zeiss, Germany). Cells of Azadinium were rare in the sample and were visually pre-identified at high magnification (640X) based on general cell size and shape. Preidentified cells were isolated by micro-capillary into wells of 96-well plates filled with $0.2 \mathrm{~mL}$ filtered seawater. By this transfer technique, the inclusion of non-target cells is unavoidable. Therefore, each primary well of isolation was subsequently partitioned in $10-\mu \mathrm{L}$ quantities distributed into 20 new wells pre-filled with $0.2 \mathrm{~mL}$ filtered seawater. Plates were incubated at $15{ }^{\circ} \mathrm{C}$ under a photon flux density of $c a .50 \mu \mathrm{mol} \mathrm{m}^{-2} \mathrm{~s}^{-1}$ on a $16: 8 \mathrm{~h}$ light:dark photocycle in a controlled environment growth chamber. From these preparations, clonal cultures were established by isolation of single cells by micro-capillary. Established cultures were routinely held at $10^{\circ} \mathrm{C}$ and $15^{\circ} \mathrm{C}(\mathrm{SHETB} 2)$ or at $15^{\circ} \mathrm{C}$ and $20^{\circ} \mathrm{C}$ (SHETF6). 
Cultures for toxin analysis were grown in plastic culture flasks at $10^{\circ} \mathrm{C}$ (A. polongum) or $20^{\circ} \mathrm{C}$ (A. spinosum) under a photon flux density of $25 \mu \mathrm{mol} \mathrm{m} \mathrm{s}^{-2}$ on a $16: 8 \mathrm{~h}$ light:dark photocycle. For A. spinosum SHETF6, $200 \mathrm{~mL}$ of a dense culture $\left(68,000\right.$ cell mL ${ }^{-1}$, cell concentration determined by counting >800 cells under an optical microscope) were harvested in 4 x 50 mL Falcon tubes by centrifugation (Eppendorf 5810R, Hamburg, Germany) at 3,220 x g for 10 min. For A. polongum SHETB2, cultures were grown in parallel in 270-mL culture flasks to a mean cell density of 2,700 cells $\mathrm{mL}^{-1}$, with $500 \mathrm{~mL}$ then harvested by centrifugation of 10 x $50 \mathrm{~mL}$. All cell pellets from one strain were combined in an Eppendorf microtube and again centrifuged (Eppendorf 5415, 16,000 x g, 5 min). The final pellet of $A$. spinosum and A. polongum were each subsequently suspended in $500 \mu \mathrm{L}$ methanol and transferred into a FastPrep tube containing 0.9 g of lysing matrix D (Thermo Savant, Illkirch, France). Sample were homogenized by reciprocal shaking at maximum speed $\left(6.5 \mathrm{~m} \mathrm{~s}^{-1}\right)$ for $45 \mathrm{~s}$ in a Bio101 FastPrep instrument (Thermo Savant, Illkirch, France) and then centrifuged (Eppendorf 5415 R, Hamburg, Germany) at 16,100 x g at $4{ }^{\circ} \mathrm{C}$ for $15 \mathrm{~min}$. Each supernatant (400 $\mu \mathrm{L})$ was transferred to a $0.45-\mu \mathrm{m}$ pore-size spin-filter (Millipore Ultrafree, Eschborn, Germany) and centrifuged for $30 \mathrm{~s}$ at $800 \mathrm{x}$ g, with the resulting filtrate transferred into an LC autosampler vial for LC-MS/MS analysis.

\subsection{Light microscopy (LM)}

Observation of living cells was carried out with a stereomicroscope (Olympus SZHILLD) and with an inverted microscope (Axiovert 200 M, Zeiss, Germany) equipped with epifluorescence and differential interference contrast optics. Light microscopic examination of the thecal plate tabulation was performed on formalin-fixed cells ( $1 \%$ final concentration) stained with calcofluor white (Fritz and Triemer, 1985). The shape and location of the nucleus was determined after staining of formalin-fixed cells for 10 min with 4'-6-diamidino-2- 
phenylindole (DAPI, $0.1 \mu \mathrm{g} \mathrm{mL} \mathrm{m}^{-1}$ final concentration). Photographs were taken with a digital camera (Axiocam MRc5, Zeiss, Germany) connected to the inverted microscope.

Cell length and width were measured at $1000 \mathrm{x}$ microscopic magnification using Zeiss Axiovision software (Zeiss, Germany) and freshly fixed cells (formalin final concentration 1\%) of a culture growing at $10^{\circ} \mathrm{C}$.

\section{3. Scanning electron microscopy (SEM)}

For SEM examination of thecal plates, cells from growing cultures were fixed, prepared, and collected on 3- $\mu$ m polycarbonate filters (Millipore) as described by Tillmann et al. (2010), with the following modification: after the $60 \%$ ethanol treatment, cells were fixed in a 60:40 mixture of deionized water and seawater containing $2 \%$ formalin for $3 \mathrm{~h}$ at $4{ }^{\circ} \mathrm{C}$ before dehydration. Filters were mounted on stubs, sputter-coated (Emscope SC500, Ashford, UK) with gold-palladium and viewed under a scanning electron microscope (FEI Quanta FEG 200, Eindhoven, Netherlands). Some SEM micrographs were presented on a black background using Adobe Photoshop 6.0 (Adobe Systems, San Jose, CA, USA).

\subsection{Morphometric measurements}

SEM photographs were used to measure pore plate dimensions of A. polongum and $A$. spinosum strains SHETF6, UTHE2, and 3D9, the latter two being archived SEM pictures. The software package Statistica (StatSoft) was used to compare pore-plate measurements (Student's t-test) for A. polongum with pooled measurements for the three $A$. spinosum strains and to plot values including 95\% confidence ellipses.

\subsection{Chemical analysis for azaspiracids}


For both new isolates, an intensive analysis for the presence of AZAs was conducted. Samples were analysed by liquid chromatography coupled to tandem mass spectrometry (LCMS/MS) according to the methods described in detail by Tillmann et al. (2009). Selected reaction monitoring (SRM) experiments were carried out in positive ion mode by selecting the following transitions (precursor ion > fragment ion): 1) AZA-1 and AZA-6: $m / z$ 842>824 collision energy (CE): $40 \mathrm{~V}$ and $\mathrm{m} / \mathrm{z}$ 842>672 CE: $70 \mathrm{~V}$, 2) AZA-2: $\mathrm{m} / \mathrm{z}$ 856>838 CE: $40 \mathrm{~V}$ and $\mathrm{m} / \mathrm{z}$ 856>672 CE: $70 \mathrm{~V}, 3$ ) AZA-3: $\mathrm{m} / \mathrm{z}$ 828>810 CE: $40 \mathrm{~V}$ and $\mathrm{m} / \mathrm{z}$ 828>658 CE: $70 \mathrm{~V}, 4$ ) AZA-4 and AZA-5: m/z 844>826 CE: 40 V, 5) AZA-7, AZA-8, AZA-9 and AZA-10: m/z 858>840 CE: $40 \mathrm{~V}$, and 6) AZA-11 and AZA-12: m/z 872>854 CE: $40 \mathrm{~V}$. The following additional mass transitions were used for new AZAs: $m / z$ 816>798, 830>812, 846>828, 868>806, 870>852 CE: $40 \mathrm{~V}$ and $\mathrm{m} / \mathrm{z}$ 816>348, 830>348, 846>348, 858>348, 868>362 CE: $70 \mathrm{~V}$.

\subsubsection{Precursor ion experiments}

Precursors of the fragments $\mathrm{m} / \mathrm{z} 348$ and $\mathrm{m} / \mathrm{z} 362$ were scanned in the positive ion mode from m/z 400 to 950 under the following conditions: curtain gas: 10 psi, CAD: medium, ion spray voltage: $5500 \mathrm{~V}$, temperature: ambient, nebulizer gas: 10 psi, auxiliary gas: off, interface heater: on, declustering potential: $100 \mathrm{~V}$, entrance potential: $10 \mathrm{~V}$, collision energy: $70 \mathrm{~V}$, exit potential: $12 \mathrm{~V}$.

\subsection{Molecular phylogenetic analysis}

The molecular analysis was conducted by the cooperation of laboratories at the LMU Munich, Germany and the IFREMER Concarneau, France. Fresh material of the strains SHETB2 and SHETF6 was sent to both of the laboratories.

In Munich, genomic DNA was extracted using the Nucleo Spin Plant II Kit (MacheryNagel, Düren, Germany) according to manufactures instructions. The complete 18S rDNA, 
the first two domains of the 28S rDNA (D1/D2 region) and the internal transcribed spacer (ITS), including the 5.8S rDNA were amplified using the primers listed in Tab. S1 (provided as supplementary material) and sequenced following standard protocols (Gottschling et al., 2012).

In Concarneau, two optional methods were used to obtain genomic DNA: DNA extraction from an exponentially growing culture of Azadinium isolate prior to DNA amplification or direct PCR amplification from 1 to 4 cells isolated from Lugol-fixed cultures. For the first approach, cells from approximately $20 \mathrm{~mL}$ of isolate SHETB2 were harvested by centrifugation (4000 rpm, $20 \mathrm{~min})$. The genomic DNA was extracted using the CTAB $(N-$ cetyl- $N, N, N$-trimethylammoniumbromide) method (Doyle and Doyle, 1987). For the second approach, cells of isolates SHETB2 or SHETF6 were respectively deposited on a glass slide, using a micropipette under the Olympus IMT2 inverted light microscope. Subsequently, the cells were placed in a drop of a sodium thiosulfate solution to decrease the inhibiting effect of the fixative on the PCR (Auinger et al., 2008), rinsed twice in double distilled water $\left(\mathrm{ddH}_{2} \mathrm{O}\right)$ before transfer to a $0.2-\mathrm{mL}$ PCR tube containing $3 \mu \mathrm{L}$ of $\mathrm{ddH}_{2} \mathrm{O}$ and stored at $-20{ }^{\circ} \mathrm{C}$ until the direct PCR. Afterwards, the 18S rDNA, 28S rDNA (D1/D2 region), and the internal transcribed spacer (ITS) including the 5.8S rDNA and COI were amplified using the primers listed in Nézan et al. (2012). Genomic DNA was amplified in 25- $\mu$ L PCR reaction containing either $1 \mu \mathrm{L}$ of extracted DNA or isolated cells, $6.5 \mu \mathrm{L}$ of ultrapure water, $2.5 \mu \mathrm{L}$ of each primer $(10 \mu \mathrm{M})$, and $12.5 \mu \mathrm{L}$ of PCR Master Mix 1X (Promega, Madison, WI, USA) which includes the Taq polymerase, $\mathrm{dNTPs}, \mathrm{MgCl}_{2}$, and reaction buffers. The PCRs were performed in a Mastercycler Personal (Eppendorf, Hamburg, Germany) as follows: one initial denaturation step at $94^{\circ} \mathrm{C}$ for $2 \mathrm{~min}$, followed by 45 cycles each consisting of $94^{\circ} \mathrm{C}$ for $30 \mathrm{~s}$, $52^{\circ} \mathrm{C}$ for $1 \mathrm{~min}$, and $72^{\circ} \mathrm{C}$ for $4 \mathrm{~min}$, and a final elongation at $72^{\circ} \mathrm{C}$ for $5 \mathrm{~min}$. The PCR products were visualized, purified and sequenced following standard protocols (Nézan et al., 2012). 
A dataset was compiled of all available Amphidomataceae sequences and a systematically representative set of dinophytes downloaded from GenBank (Tab. S2, provided as supplementary material). To avoid the effect of "long branch attractions", only taxa of similar branch length were chosen as outgroups. 'MAFFT'” v6.624b (Katoh and Toh, 2008; freely available at http://mafft.cbrc.jp/alignment/software/index.html) was used to align the sequences automatically. The alignment is available via nexus file upon request. Phylogenetic analyses were carried out using Maximum-Likelihood (ML) and Bayesian approaches, as described in detail previously (Gottschling et al., 2012). The Bayesian analysis was performed using “'MrBayes”’ v3.1.2 (Ronquist and Huelsenbeck, 2003; freely available at http://mrbayes.sourceforge.net/download.php) under the GTR+C substitution model and the random-addition-sequence method with 10 replicates. We ran two independent analyses of four chains (one cold and three heated) with 20,000,000 cycles, sampled every 1,000th cycle, with an appropriate burn-in (10\%, after checking convergence). For the ML calculation, “'RaxML”, v7.2.6 (Stamatakis, 2006; freely available at http://www.kramer.in.tum.de/exelixis/software.html) was applied using the GTR + CAT substitution model to search for the best-scoring ML tree and a rapid bootstrap analysis of 500 non-parametric replicates. Statistical support values (LBS: ML bootstrap support, BPP: Bayesian posterior probabilities) were drawn on the resulting, best-scoring ML tree. The calculation of the pairwise genetic distance $p$ was conducted using Mega version 5.0 (Tamura et al., 2011). 


\section{Results}

Specimens of Azadinium were observed in concentrated whole water samples at four out of six stations along the west coast of the Shetlands and from one of these stations, two clonal cultures could be established. Cells of both cultures showed rather slow swimming speed interrupted by sudden jumps in various directions, behavioural traits previously described for members of the genus (Tillmann et al., 2009). From the onset, however, the two isolates displayed marked physiological differences, indicating that they might represent different species: Strain SHETF6 exhibited rapid growth at $15{ }^{\circ} \mathrm{C}$ and reached high cell densities at stationary phase (about 100,000 cells $\mathrm{mL}^{-1}$ ), whereas strain SHETB2 grew much more slowly, reaching maximal cell densities of $<3,000$ cells $\mathrm{mL}^{-1}$. The cultures seem to have different temperature requirements, with cell densities of SHETB2, but not SHETF6, rapidly declining when cultures were grown at $20^{\circ} \mathrm{C}$. In addition, cysts were regularly observed in cultures of SHETB2, but not SHETF6.

Morphological attributes of strain SHETF6 supported identification of this isolate as Azadinium spinosum (Fig. 1). Concordant with previous descriptions of the species, the cells are slender and elongated (Fig. 1 B), with LM revealing an antapical spine and one conspicuous pyrenoid located in the epicone (Fig. 1 A). Plate pattern, plate size and arrangement (Fig. 1 D-E), as well as presence and location of the ventral pore (Fig. $1 \mathrm{C}$ ) are in total agreement with previous description of the type material for A. spinosum (Tillmann et al., 2009). Toxin analysis and rDNA sequence also reinforced identification of strain SHETF6 as A. spinosum (see below).

Examination of cell morphology, rDNA sequence, and toxin profile (see below) supported placement of isolate SHETB2 in the genus Azadinium, as a new species. 


\section{Diagnosis:}

Differs from Azadinium spinosum in the elongated shape of the pore plate Po and the X-plate, the smaller size of plate 2a, the location of the ventral pore and the absence of a distinct pyrenoid with starch sheath. Distinguished from both A. obesum and A. poporum by the presence of an antapical spine. The Kofoidian plate tabulation is: Po, cp, X, 4', 3a, 6" , 6C, 5?S, 6"', 2"'”. Cell length 10 to $17 \mu \mathrm{m}$, cell width 7 to $14 \mu \mathrm{m}$.

HOLOTYPE : A SEM-stub (strain SHETB2, Stub designation CEDiT2012H20), and a formalin fixed sample (strain SHETB2, designation CEDiT2012I21) have been deposited at the Senckenberg Research Institute and Natural History Museum, Centre of Excellence for Dinophyte Taxonomy, Germany. Fig. 4 has been chosen to represent the type in accordance to fulfil article 39.1 of the International Code of Botanical Nomenclature (ICBN).

TYPE LOCALITY: $60^{0} 12.73^{\prime}$ N, $0^{0}$ 59.90’ W, Shetland Islands

HABITAT : marine plankton

ETYMOLOGY: the epithet is inspired by the conspicuously elongated shape of the pore plate ('Po'= designation for pore plate; longus (Latin) = long). The epithet is indeclinable.

\section{Cell morphology}

Cells of A. polongum are ovoid and, if at all, only slightly dorso-ventrally compressed. The episome ends with a conspicuous apical pore complex (APC) and is slightly larger than the hyposome (Fig. 2). The cingulum is deep and wide. Cells are generally small but quite variable in size, ranging from 10.1-17.4 $\mu \mathrm{m}$ in length and 7.4-13.6 $\mu \mathrm{m}$ in width (median length: $13.0 \mu \mathrm{m}$, median width $9.7 \mu \mathrm{m}, n=107)$, with a median length/width ratio of 1.3 . The large nucleus is spherical to slightly elongated and is located in the central part of the cell (Fig. 2 E). The presumably single chloroplast is parietally arranged, lobed, and extends into the epi- and hyposome (Fig. 2). Light-microscopy did not indicate the presence of pyrenoid(s) 
with starch sheath. However, cells may have a number of large starch grains as indicated by positive Lugol staining (Fig. 2 D).

Cells of $A$. polongum possess delicate thecal plates, which can be readily seen in the light microscope (Fig. 2) and stained with calcofluor white (not shown). However, the plate pattern was most easily resolved by SEM (Figs. 3, 5-7). Generally, the surface of the plates is smooth but a few pores of different sizes are irregularly scattered over the plates. The basic thecal plate arrangement was: Po, cp, X, 4', 3a, 6"', 6C, 5?S, 6"', 2"'”, as drawn in Fig. 4.

The apical series is composed of four plates (Fig. 5). Plate 1' has an ortho pattern, but slightly asymmetric, with the suture joining plate 6 "' being shorter than that joining plate $1^{\prime \prime}$ (Fig. 5 C). In its anterior part, plate $1^{\prime}$ is progressively narrowed, ending in a slender tip abutting the pore plate. A ventral pore located at the border of plate $1^{\prime}$ and $1^{\prime \prime}$ is present at the lower third level of the epitheca (Figs. 5 C, 7 G-H). This pore has a distinct outer rim that measure $0.35 \pm 0.02 \mu \mathrm{m}$ and $0.21 \pm 0.01 \mu \mathrm{m}(\mathrm{n}=10)$ for outer and inner diameter, respectively. Comparing the lateral apical plates $2^{\prime}$ and $4^{\prime}$, the left plate $4^{\prime}$ is slightly larger. Both plates clearly invade the ventral area, with their tapering posterior ends pointing towards the sulcus. Dorsal apical plate $3^{\prime}$ is 6-sided, small, and elongated posteriorly, ending in a narrow tip that abuts the small intercalary plate 2a. Three intercalary plates are arranged more or less symmetrically on the dorsal side of the epitheca. The intercalary plates are very different in size, with the four-sided plate 2a being distinctively smaller than the two other intercalary plates (Fig. 5 A-B, D).

Within the series of six precingular plates, plate $6^{\prime \prime}$ is the smallest. Plate $1^{\prime \prime}$ is in contact with an intercalary plate (1a) and thus contacts four epithecal plates, whereas plate 6 "' is narrower and only contacts three epithecal plates (Fig. 5).

The hypotheca consists of six postcingular and two antapical plates (Fig. 6 A-B). The ventrally located plates $1^{\prime \prime \prime}$ and $6^{\prime \prime \prime}$ are the smallest four-sided plate $5^{\prime \prime \prime}$ is the largest in the postcingular series. Plate $3^{\prime \prime \prime}$ is in contact with both antapical plates (Fig. 6 A-B). The two 
antapical plates are of markedly different size, with the smaller plate $1^{\prime \prime \prime \prime}$ slightly displaced to the left. The larger antapical plate $2^{\prime \prime \prime}$ is bearing a small antapical spine that is usually accompanied by a small cluster of pores. The position of the spine is slightly variable, ranging from an axial position (e.g. Fig. 6 C) to being slightly shifted to cells right side (e.g. Fig. 3 A). Occasionally, the spine arise from a small bump (Fig. 7 F).

The cingulum is wide (e.g 2.6 to $2.9 \mu \mathrm{m}$, Figs 3 A-B, 6 C), descending, and displaced by about half of its width. Narrow cingular lists are present. The cingulum is composed of six comparably sized plates, but plate C6 is more slender than the others (Fig. 6 C-D).

Furthermore, plate C6 is asymmetric in shape, with a conspicuous S-shaped extension partly covering the sulcal area and the flagellar pore region (Figs. 3 A-B, 6 C). The deeply concave sulcus (Fig. 6 C-D) consists of a large anterior sulcal plate (Sa) that partly invades the epitheca, and a large posterior sulcal plate (Sp) that extends two-thirds of the way from the cingulum to the antapex. A left sulcal plate, Ss, is located anterior to Sp and abuts plates $1^{\prime \prime \prime}$, C1, Sa, Sd, Sm, Sp and C6. The right sulcal plate Sd abuts sulcal plates Ss and Sm, as well as cingular plate C6. The median sulcal plate Sm contacts sulcal plates Sa, Ss and Sd (Fig. 6 CD). As in other species of Azadinium, these plates have an apparently complicated threedimensional morphology, with large flanges invading into the hypotheca (see Fig. 6 D).

The apical pore complex (Fig. 7 A-E) is distinctly elongated, with the apical pore being round or slightly ellipsoid (Fig. 7 A-B) and shielded by a cover plate. The pore is located in the dorsal part of an elongated pore plate, the latter having a roundish dorsal part that is considerable prolonged ventrally. A conspicuous rim borders the dorsal and lateral margins of the pore plate adjacent to apical plates $2^{\prime}, 3^{\prime}, 4^{\prime}$, but it is lacking ventrally where the pore plate abuts the first apical plate and the X-plate. When viewed from inside the cell, the Xplate is obviously slender and elongated (Fig. 7 C-E). The X-plate has a mean length of 0.75 $\mu \mathrm{m}(0.65-0.83, \mathrm{n}=7)$ and penetrates most of the elongated part of the pore plate. Ventrally, the X-plate abuts but does not invade the first apical plate. Occasionally, the X-plate appears to be 
slightly displaced into the pore plate, but is still connected to the 1'plate by a narrow slit (Fig. 7 B, D). The X-plate has a very characteristic three-dimensional structure, with finger-like protrusions contacting the cover plate (Fig. 7 A-B).

Growth bands are visible as faint striated rows (Fig. 5 A) present at overlapping plate margins. The plate overlap pattern was elucidated mainly from internal thecal views (see Fig. S1 provided as supplementary material and Fig. 7 E) and is schematised in Fig. 4 C-D.

A number of deviations from the typical plate pattern shown in Fig. 4 were observed. Although not explicitly quantified, these variations primarily consist of extra sutures between the epithecal plates, either of the precingular or apicals plates $2^{\prime}$ or $4^{\prime}$. In addition, cells lacking the intercalary plate 2a or with two small intercalary plates have been recorded (Fig. S2, provided as supplementary material).

Round cysts-like cells ranging in size from about 10 to $16 \mu \mathrm{m}$ in diameter were regularly observed in cultures of A. polongum (Fig. 8). While cyst formation was not followed closely, the cells depicted in Fig. 8 A-C appear to represent early cysts stages. These "early cysts”, as observed in LM, are completely round, golden-brown in color and densely filled with large droplets, presumably representing reserve material. Epifluorescence microscopy indicates the presence of an intact chloroplast at this stage of cyst development (Fig. $8 \mathrm{C}$ ). The majority of cysts, however, are almost colorless with pale white inclusions in LM; however, fluorescence microscopy revealed different stages of pigment reduction (Fig. 8 D-E). The outer cyst layer appears thick and smooth in LM, although very fine radiating fibers seem to be present (Fig. 8 F). In SEM, cysts are sometimes partly covered by thecal plates (Fig. 8 G) or are covered by a dense fibrous mesh of filaments (Fig. $8 \mathrm{H}-\mathrm{I})$.

\section{Morphometric analysis}

The pore plates of A. polongum (strain SHETB2) and A. spinosum (strains 3D9, UTHE2 and SHETF6) showed no significant difference in width (largest left-to-right distance for the 
dorsal part of the Po) (Fig. 9 A), ranging from 1-1.5 $\mu \mathrm{m}$ in both species. However, the length of the pore plate of $A$. polongum ( $2.1 \pm 0.2$, mean \pm STD, $n=65)$ was significantly different from that of $A$. spinosum $(1.5 \pm 0.1$, mean \pm STD, $n=57)$, (t-test, $\mathrm{p}<0.001)$. A scatter plot of pore plate length vs. length-width ratio (Fig. 9 B) clearly separates the data points on both axes thereby underlining the difference in plate morphometry between the two species.

\section{Toxin analysis}

Using the selected reaction monitoring mode (SRM), A. spinosum SHETF6 exhibited a toxin profile of known AZAs consisting of AZA-1, and AZA-2, identical to previously isolated strains of the species. Combined cell quotas of AZA-1 and -2 from two different cultures of strain SHETF6 ranged from 19 to 22 fg per cell, with an AZA1/AZA2 ratio ranging from 1.9 to 2.8. The presence of other AZAs of known molecular mass can be excluded with a detection limit of $1.1 \mathrm{pg}$ on column, corresponding to per cell detection limit of 0.008 fg. Using SRM, none of previously described AZAs were found in A. polongum at a detection limit of $1.1 \mathrm{pg}$ on column (due to lower sample biomass corresponding to a per cell detection limit of $0.08 \mathrm{fg})$.

In addition, precursor ion experiments for detecting putative precursor masses of the characteristic CID-fragments $\mathrm{m} / \mathrm{z} 348$ and $\mathrm{m} / \mathrm{z} 362$ of AZAs revealed A. spinosum SHETF6 to have a previously undescribed AZA of the $\mathrm{m} / \mathrm{z} 362$ fragment type with a molecular mass of 715 Da. Peak area of this AZA accounted for $30 \%$ of the AZA-1 peak, indicating that this compound was a quantitatively important component of the A. spinosum total AZA profile. Precursor ion scans did not give any further signals for either SHETB2 (A. polongum) or SHETF6 (A. spinosum), indicating that neither strain produced other unknown AZA variants in larger amounts. However, the precursor on mode is approximately a hundred times less sensitive than the SRM mode and strictly speaking does not allow for exact quantitative measurement. Considering a conservatively determined "detection limit” of 0.2 ng on column, 
this represents a cellular detection limit of unknown AZA variants of $1 \mathrm{fg}^{\text {cell }^{-1}}$ (A. spinosum SHETF6) or $10 \mathrm{fg} \mathrm{cell}^{-1}$ (A. polongum SHET B2).

Sequence data and phylogeny

The total length of the rDNA alignment for 33 taxa in total, including 15 ingroup and 18 outgroup taxa having comparable branch length, was 3351 bases long with 907 sites being parsimony informative (pi; 27\%, 27.5 per terminal taxon). The SSU covered 1822 bases with 145 pi sites (8\%), the ITS region 718 bases with 435 pi sites (61\%) and the first two domains of the LSU covers 811 bases with 327 pi sites (40\%). COI sequences showed zero to one nucleotide difference between different Azadinium species (data not shown). Tree topologies inferred from Bayesian and ML approaches were largely congruent. The best scoring ML tree is shown in Fig. 10. Many nodes had high or maximum support. Established taxonomic units such as Thoracosphaeraceae (95LBS, 0.83BPP), Gymnodinales 1 (100LBS, 1.00BPP), Gymnodinales 2 (96LBS, 1.00BPP) and Prorocentrales (100LBS, 1.00BPP) were formed. The Amphidomaceae were monophyletic (99LBS, 1.00BPP), with Amphidoma being most basal and Azadinium monophyletic with maximum support (100LBS, 1.00BPP). Within Azadinium, five species (A. polongum sp. nov. being one of them) were clearly separated and distinguishable. The results of the genetic distance analysis among Amphidomatacea are given in Tab. 1. The variation of the ITS region covering ITS1, 5.8S rRNA and ITS2 between Azadinium species, varieties, or different strains (in the case of A. poporum from Europe and A. cf. poporum from Korea) varied between 0.023 and 0.247 . Other available strains of the same species, which are not listed in Tab. 1, exhibited the same genetic distances as the listed strain.

\section{Discussion}


The occurrence of Azadinium along the Scottish coast (North Sea) (Tillmann et al., 2009; Tillmann et al., 2010) and the Irish Atlantic coast (Salas et al., 2011), as well as a report of AZA in mussels from the north coast of Norway (Torgersen et al., 2008), suggest a distribution of the genus into more northern North Sea/Atlantic waters, an hypothesis confirmed by the present record from the Shetland Islands.

The Shetland Islands form the border between North Sea and Atlantic Ocean (International-Hydrographic-Organisation, 1953) with eastern Shetland Islands located in the North Sea and western Islands belonging to the Atlantic Ocean. According to that definition, the locality of our Azadinium record is situated in the North Sea. However, this area is heavily influenced by the East Shetland Atlantic Inflow, with Atlantic water therefore found on both sides of the Shetlands (Maravelias and Reid, 1997). Thus, occurrence of Azadinium in the North Atlantic is quite likely. During our cruise we failed to detect Azadinium and azaspiracids at a few stations adjacent to the more northerly located Faroe Islands (unpublished), but that negative observation may have been due to extremely low algal densities probably caused by high abundances of copepods..

Surface water temperature around the Shetlands is quite stable annually, rarely exceeding $12{ }^{\circ} \mathrm{C}$ during summer (Becker and Pauly, 1996). During our cruise, sea surface temperature was around $10^{\circ} \mathrm{C}$. Although not studied in detail, lab cultures of $A$. spinosum seemed to grow over a broad range of temperatures, however, best growth occurred at higher temperature (20 ${ }^{\circ} \mathrm{C}$ ). In contrast, A. polongum grew well at $10^{\circ} \mathrm{C}$, but died rapidly at higher temperatures, indicating that this species is more stringently adapted and thus more restricted to lower temperatures.

We observed specimens of Azadinium spp. at four out of six stations along the west coast of the Shetlands, but their abundances were generally very low. As indicated by qualitative inspection of net tows and whole water samples, the plankton was generally characterized as an early post-spring bloom community, with high abundance of copepods, diatoms present in 
varying numbers, and occurrence of different dinophytes (e.g. Prorocentrum minimum

(Pavillard) Schiller, various species of Protoperidinium). In agreement with the A. spinosum record from the Shetlands, AZA-1 was detected at two of the Shetland west coast stations (including the station, where strain SHETF6 was isolated), however, only in low amounts ranging up to $0.02 \mathrm{ng} \mathrm{L}^{-1}$ (unpublished).

One of our two Azadinium isolates, strain SHETB2, was identified as a new species. While the characteristic swimming pattern of SHETB2 strongly indicates its affiliation with Azadinium, it is the genus characteristic Kofoidian thecal plate tabulation (Po, cp, X, 4', 3a, $6^{\prime \prime} .6 \mathrm{C}, 5$ ?S, 6"', 2"'”) that places this new taxon in the dinophyte genus Azadinium (Tillmann et al., 2009). Furthermore, discrimination of this taxon at the species level is justified by a number of distinctive morphological features. The most obvious is the shape of the pore plate that allows a clear separation of A. polongum (elongated pore plate) from other Azadinium species (round to ellipsoid pore plate, see Fig. 11). The difference in shape of the X-plate (elongated in A. polongum; round to ellipsoidal in other Azadinium species) might be related to the elongated shape of the pore plate of $A$. polongum. The X-plate also shows differences in arrangement across species. It invades the first apical plate in $A$. spinosum, $A$. obesum and A. poporum, but abuts the first apical plate in A. polongum and A. caudatum (Nézan et al., 2012). The shape and size of the dorsal intercalary plate 2a was variable in our culture material of A. polongum (see Fig. S2, provided as supplementary material). Nevertheless, in its normal condition, plate 2a of A. polongum is distinctly smaller than that of other small Azadinium species and is anteriorly linked to the elongated antapical portion of plate $3^{\prime}$. These characteristic features are not found in A. spinosum, A. obesum and A. poporum (Tillmann et al., 2009; Tillmann et al., 2010; Tillmann et al., 2011) and more closely resemble the configuration of $A$. caudatum (Nézan et al., 2012). 
The ventral pore, which is a characteristic feature of all Azadinium species, is more posteriorly positioned in A. polongum than in other species, being located in the lower third epitheca between plate $1^{\prime}$ and $1^{\prime \prime}$. Moreover, for A. polongum, the ventral pore is clearly located on the suture and is embedded in a cavity of plate 1' (see Fig. 7 G-H) whereas for A. spinosum it is located within the $1^{\prime}$ plate and is connected to the suture of $1^{\prime}$ and $1^{\prime \prime}$ by a narrow slit (Tillmann et al., 2009). Generally, the location of the ventral pore seems to be variable in Azadinium species, either on the left margin of plate 1' (A. spinosum, A. obesum) or on the left side of the Po (A. poporum) (Tillmann et al., 2009; Tillmann et al., 2010; Tillmann et al., 2011). In A. caudatum var. margalefii, this pore is located on the right margin of the Po whereas for the second variety, A. caudatum var. caudatum, a similar pore is situated near the posterior right margin of plate 1' (Nézan et al., 2012). In the closely related Amphidoma species, Kofoid and Michener (1911) reported this pore on right edge of $1^{\prime}$ (A. elongata Kofoid et Sweezy) or at the midventral posterior tip of 1' (A. laticincta Kofoid et Sweezy) while in Amphidoma languida, it is located on the anterior right margin of 1' (Tillmann et al., 2012). Very rarely, the position of the ventral pore has been observed to vary even within a culture. In one specimen of $A$. languida, the ventral pore was located in the right side of the pore plate (Tillmann et al., 2012), as in A. caudatum var. margalefii, and, in one specimen of A. poporum isolated from Korea, it was located on the left side of plate $1^{\prime}$ (Potvin et al., 2012). As the function (if any) of these pores is completely unknown, we cannot speculate on the potential consequences of the apparent variability in pore location among the Amphidomataceae.

The potential affinity of a few other described Dinophycean species (Gonyaulax parva Ramsjfell, G. gracilis Schiller) to Azadinium has been discussed before (Tillmann et al., 2011). G. parva clearly differs from A. polongum by the intercalary plates having the same size. The taxonomy of G. gracilis and specimens depicted under this name (see Tillmann et al., 2011) generally needs careful revision. At least one specimen depicted as G. gracilis by 
Berard-Therriault et al. (1999) probably is a species of Azadinium. It has an antapical spine but other details are not visible, and we thus cannot exclude the possibility of that specimen being A. polongum.

In terms of plate overlap pattern, the new species $A$. polongum exactly resembles the type A. spinosum as described by Tillmann \& Elbrächter (2010). Peculiarities in plate overlap of $A$. spinosum, including 3' overlapped by the adjacent apical plates 2' and 4' (see Fig. 7 E), plate 2a overlapped by all adjacent plates, and Sa overlapping plate C6, are also present in $A$. polongum (see Fig. S1, provided as supplementary material), thus indicating a conservative plate overlap pattern for the genus. However, A. caudatum has been found to exhibit a slightly different overlap pattern of the ventral apical plates in that plate $1^{\prime}$ overlaps the adjacent apical plates 2' and 4' (Nézan et al., 2012).

Differences in morphology between SHETB2 and SHETF6 are additionally reflected by differences in the biology/autecology of both isolates. The different growth behavior in terms of temperature requirement has been addressed above. Strikingly, final cell yield of $A$. spinosum SHETF6 was much higher compared to A. polongum indicating different nutrient or carbon requirements and/or pH tolerance (Hansen et al., 2007). Moreover, A. polongum produced cysts in culture, a feature not yet observed for other Azadinium species. However, successful isolation of $A$. poporum by incubating sediment samples (Potvin et al., 2012) make the presence of cyst quite likely for A. poporum. We currently know little about the nature of A. polongum cysts. SEM failed to detect any external cyst structures like paratabulation and/or archeopyle, and hatching was not observed. The reduced chlorophyll fluorescence of cysts (Fig. 8 D-E) and their long persistence in an apparently unaltered state indicate that $A$. polongum cysts might allow long term survival (hypnocysts), rather than serving as temporary cysts. If true, these hypnocysts might be part of the vegetative cycle (as has been observed for Scrippsiella hangoei (J. Schiller) J. Larsen, see Kremp and Parrow, 2006), or part of a sexual 
life cycle. Clearly, more data and observations are needed to clarify the whole life cycle of Azadinium.

Separate dinophyte lineages and different sites of rDNA have contrasting evolutionary rates (Hoppenrath and Leander, 2010). To avoid the disadvantages of single site phylogenies and to balance different rates of evolution, we combined slow sites like the SSU with quickly evolving sites like the ITSs. Various ratios of parsimony information for the regions have been demonstrated before (Gottschling et al., 2012) and were confirmed here. With 61\% of the positions as parsimony informative, the ITS region holds the main portion of phylogenetic information. With only $8 \%$, the SSU seems to be much less informative. Nevertheless, for higher taxonomic analysis and the inclusion of many taxa, such slowly evolving sites are valuable to stabilize the analysis and to support the resolution of the basal nodes. In our analysis, the basal nodes and phylogenetic relationships were not resolved with high support; however, well established taxonomic units such as the Thoracosphaeraceae (95LBS, 0.83BPP), the Gymnodinales 1 (100LBS, 1.00BPP), the Gymnodinales 2 (96LBS, 1.00BPP), and the Prorocentrales (100LBS, 1.00BPP) were distinguished.

Together with Amphidoma languida the monophyletic and maximum supported Azadinium (100LBS, 1.00BPP) forms the highly supported Amphidomataceae (99LBS, 1.00BPP) (Tillmann et al., 2012). In total, five species are now clearly distinguishable within Azadinium (Tillmann et al., 2009; Tillmann et al., 2010; Tillmann et al., 2011; Nézan et al., 2012), and the relatively high genetic distances of the ITS region (Tab. 1) support the species delimitations (Litaker et al., 2007). The genetic distance of the new species Azadinium polongum (SHETB2) to the other small Azadinium species (A. spinosum, A. obesum, A. poporum, $\mathrm{p}=0.180-0.187)$ is distinctly larger than the distance among these other small species ( $\mathrm{p}=0.052-0.105)$. SHETF6 could be added as a new strain of $A$. spinosum clustering to the other A. spinosum not only by morphology and toxins, but also by molecular evidence. 
Toxin analysis of both Shetland-strains for known AZAs verified AZA-1 and -2 production solely for $A$. spinosum at a cell quota comparable to other isolates (Tillmann et al., 2009; Salas et al., 2011; Tillmann et al., 2011; Jauffrais et al., 2012), indicating the toxin content and profile as a stable characteristic in this species. In addition to AZA-1 and -2, a yet undescribed AZA of the $\mathrm{m} / \mathrm{z}$ 362-fragment type with a molecular mass of $715 \mathrm{Da}$ is here reported for A. spinosum for the first time. This compound also has been found in significant amounts in all other $A$. spinosum strains, and a manuscript including NMR structural elucidation is in preparation (Kilcoyne et al., manuscript in preparation). Production of AZAs within the genus was initially known only for A. spinosum, but is apparently more common within the Amphidomataceae. A. languida and A. poporum are now known to produce a new type of azaspiracid characterised by a modified fragment of $m / z 348$ compared to the fragment of $m / z 362$ characteristic for the previously known AZAs (Krock et al., 2012). We tested both Shetland-strains for the presence of known AZAs of both fragment types and detected only AZA-1 and-2 in A. spinosum. Although, we cannot exclude the presence of other yet unknown AZAs (in addition to the new 715 Da AZA), as the precursor ion scan method is much less sensitive than the single reaction mode (limit of detection of our measurement estimated ca. 1 and 10 fg per cell for SHETF6 and SHETB2, respectively). Patently, more analyses using larger culture volumes are needed. Nevertheless, A. polongum clearly is not toxigenic for known AZAs and thus represents another case of coexisting toxigenic and nontoxigenic species of Azadinium, as previously described for A. obesum (Tillmann et al., 2010).

Considering the short interval since the first identification of Azadinium, the diversity of the genus has increased rapidly, with five species now described and additional new species expected. The presence of an antapical spine in small Azadinium species was hitherto restricted to $A$. spinosum. With $A$. polongum also exhibiting an antapical spine, the 
identification of the toxigenic species $A$. spinosum only by light microscopy is unfortunately no longer convenient. A. caudatum also has a spine, however of distinctly different size and shape. Fortunately, a molecular approach that can be routinely applied to a larger number of field samples has been developed to identify A. spinosum and related taxa (Töbe et al., 2013). This approach may thus be used to unambiguously confirm microscopic species assignments, like the assured presence of $A$. spinosum in the Black Sea ((http://phyto.bss.ibss.org.ua/wiki/Azadinium_spinosum) and the presence of A. cf. spinosum in Argentinean coastal waters (Akselman and Negri, 2012).

\section{Acknowledgment}

We are grateful to Gwenaël Bilien (IfREMER, Concarneau) and Karine Chèze (MNHN, Concarneau) for their contribution to molecular analysis. We greatly acknowledge Wayne Coats for many helpful suggestions and correcting the English. Thanks to Captain Voss and the Heincke crew for their assistance and support for the collection of field material. Financial support was provided by the PACES research program of the Alfred Wegener Institute as part of the Helmholtz Foundation initiative in Earth and Environment. This work is part of the project “Azaspiracids: Toxicological Evaluation, Test Methods and Identification of the Source Organism” (PBA/AF/08/001(01) which is carried out under the Sea Change strategy with the support of the Marine Institute and the Marine Research Sub-Programme of the National Development Plan 2007-2013, co-financed under the European Regional Development Fund. 
References

Akselman, R., Negri, A., 2012. Blooms of Azadinium cf. spinosum Elbrächter et Tillmann (Dinophyceae) in northern shelf waters of Argentina, Southwestern Atlantic. Harmful Algae in press, http://dx.doi.org/10.1016/j.hal.2012.05.004

Alvarez, G., Uribe, E., Avalos, P., Marino, C., Blanco, J., 2010. First identification of azaspiracid and spirolides in Mesodesma donacium and Mulinia edulis from Northern Chile. Toxicon 55, 638-641

Amzil, Z., Sibat, M., Royer, F., Savar, V., 2008. First report on azaspiracid and yessotoxin groups detection in French shellfish. Toxicon 52, 39-48

Auinger, B.M., Pfandl, K., Boenigk, J., 2008. Improved methodology for identification of protists and microalgae from plankton samples preserved in Lugol's iodine solution: combining microscopic analysis with single-cell PCR. Appl. Environ. Microbiol. 74, 2505-2510

Becker, G.A., Pauly, M., 1996. Sea surface temperature changes in the North Sea and their causes. ICES J. mar. Sci. 53, 887-898

Bérard-Therriault, L., Poulin, M., Bossé, L., 1999. Guide d’identification du phytoplancton marin de l'estuaire et du golfe de Saint-Laurent incluant également certaines protozoaires. Publication spéciale canadienne des sciences halieutiques et aquatiques 128, 1-387

Brana Magdalena, A., Lehane, M., Krys, S., Fernandez, M.L., Furey, A., James, K.J., 2003. The first identification of azaspiracids in shellfish from France and Spain. Toxicon 42, 105-108

Dodge, J.D., Saunders, R.D., 1985. An SEM study of Amphidoma nucula (Dinophyceae) and description of the thecal plates in A. caudata. Arch. Protistenkd. 129, 89-99

Doyle, J.J., Doyle, J.L., 1987. A rapid DNA isolation procedure for small quantities of fresh leaf tissue. Phytochemical Bulletin 19, 11-15

Fritz, L., Triemer, R.E., 1985. A rapid simple technique utilizing Calcofluor white M2R for the visualization of dinoflagellate thecal plates. J. Phycol. 21, 662-664

Furey, A., O'Doherty, S., O'Callaghan, K., Lehane, M., James, K.J., 2010. Azaspiracid poisoning (AZP) toxins in shellfish: Toxicological and health considerations. Toxicon 56, 173-190

Gottschling, M., Soehner, S., Zinssmeiste, C., John, U., Plötner, J., Schweikert, M., Aligizaki, K., Elbrächter, M., 2012. Delimitation of the Thoracosphaeraceae (Dinophyceae), including the calcareous dinoflagellates, based on large amounts of ribosomal RNA sequence data. Protist 163, 15-24

Hansen, P.J., Lundholm, N., Rost, B., 2007. Growth limitation in marine red-tide dinoflagellates: effects of $\mathrm{pH}$ versus inorganic carbon availability. Mar. Ecol. Prog. Ser. 334, 63-71

Hernandez-Becerril, D.U., Escobar-Morales, S., Morreno-Gutiérez, S.P., Baron-Campis, S.A., 2010. Two new records of potentially toxic phytoplankton species from the Mexican Pacific. Abstract book of the 14th International conference on harmful algae, Greece, 137

Hoppenrath, M., Leander, B.S., 2010. Dinoflagellate phylogeny as inferred from Heat Shock Protein 90 and ribosomal gene sequences. PLoS One 5, e13220, doi:10.1371/journal.pone.0013220

International-Hydrographic-Organisation, 1953. Limits of the Oceans and Seas. IMP, Monegasque, Monte Carlo.

Jauffrais, T., Herrenknecht, C., Séchet, V., Sibat, M., Tillmann, U., Krock, B., Kilcoyne, J., Miles, C.O., McCarron, P., Amzil, Z., Hess, P., 2012. Quantitative analysis of 
azaspiracids in Azadinium spinosum cultures. Analytical and Bioanalytical Chemistry 403, 833-846

Katoh, K., Toh, H., 2008. Improved accuracy of multiple ncRNA alignment by incorporating structural information into a MAFFT-based framework. BMC Bioinformatics doi: 10.1186/1471-2105-9-212.,

Kofoid, C.A., Michener, J.R., 1911. Reports on the Scientific Results of the Expedition to the Eastern Tropical Pacific, in Charge of Alexander Agassiz, by the U.S. Fish Commission Steamer „ALBATROSS,“ from October 1904, to March, 1906, Lieut. L.M. Garrett, U.S.N., Commanding . XXII. New genera and species of Dinoflagellates. Bulletin of the Museum of Comparative Zoology at Havard College 54, 267-302

Kremp, A., Parrow, M.W., 2006. Evidence for asexual resting cysts in the life cycle of the marine perdinoid dinoflagellate, Scrippsiella hangoei. J. Phycol. 42, 400-409

Krock, B., Tillmann, U., John, U., Cembella, A.D., 2009. Characterization of azaspiracids in plankton size-fractions and isolation of an azaspiracid-producing dinoflagellate from the North Sea. Harmful Algae 8, 254-263

Krock, B., Tillmann, U., Voß, D., Koch, B.P., Salas, R., Witt, M., Potvin, E., Jeong, H.J., 2012. New azaspiracids in Amphidomataceae (Dinophyceae): proposed structures. Toxicon 60, 830-839

Litaker, R.W., Vandersea, M.W., Kibler, S.R., Reece, K.S., Stokes, N.A., Lutzoni, F.M., Yonish, B.A., West, M.A., Black, M.N.D., Tester, P.A., 2007. Recognizing dinoflagellate species using ITS rDNA sequences. J. Phycol. 43, 344-355

Maravelias, C.D., Reid, D.G., 1997. Identifying the effects of oceanographic features and zooplankton on prespawning herring abundances using generalised additive models. Mar. Ecol. Prog. Ser. 147, 1-9

Nézan, E., Tillmann, U., Bilien, G., Boulben, S., Chèze, K., Zentz, F., Salas, R., Chomérat, N., 2012. Taxonomic revision of the dinoflagellate Amphidoma caudata: transfer to the genus Azadinium (Dinophyceae) and proposal of two varieties, based on morphological and molecular phylogenetic analyses. J. Phycol. DOI: 10.1111/j.15298817.2012.01159.x,

Ofuji, K., Satake, M., McMahon, T., Silke, J., James, K.J., Naoki, H., Oshima, Y., Yasumoto, T., 1999. Two analogs of Azaspiracid isolated from mussels, Mytilus edulis, involved in human intoxication in Ireland. Nat. Toxins 7, 99-102

Potvin, E., Jeong, H.J., Kang, N.S.T., Tillmann, U., Krock, B., 2012. First report of the photosynthetic dinoflagellate genus Azadinium in the Pacific Ocean: Morphology and molecular characterizationof Azadinium cf. poporum. J. Eukaryot. Microbiol. 59, 145156

Ronquist, F., Huelsenbeck, J.P., 2003. MrBayes 3: Bayesian phylogenetic inderence under mixed models. Bioinformatics 19, 1572-1574

Salas, R., Tillmann, U., John, U., Kilcoyne, J., Burson, A., Cantwell, C., Hess, P., Jauffrais, T., Silke, J., 2011. The role of Azadinium spinosum (Dinophyceae) in the production of Azasdpiracid Shellfish Poisoning in mussels. Harmful Algae 10, 774-783

Satake, M., Ofuji, K., James, K., Furey, A., Yasumoto, T., 1998. New toxic events caused by Irish mussels. In: Reguera, B., Blanco, J., Fernandez, M.L., Wyatt, T. Eds. Harmful Algae. Xunta de Galicia and Interantional Oceanographic Commission of UNESCO, Santiago de Compostela, pp 468-469

Stamatakis, A., 2006. RAxML-VI-HPC: Maximum likelihood-based phylogenetic analyses with thousands of taxa and mixed models. Bioinformatics 22, 2688-2690

Taleb, H., Vale, P., Amanhir, R., Benhadouch, A., Sagou, R., Chafik, A., 2006. First detection of azaspirazids in mussels in north west Africa. J. Shellfish Res. 25, 1067-1070 
Tamura, K., Peterson, D., Peterson, N., Stecher, G., Nei, M., Kumar, S., 2011. MEGA5: Molecular Evolutionary Genetics Analysis using Maximum Likelihood, Evolutionary Distance, and Maximum Parsimony Methods. Mol. Biol. Evol. 28, 2731-2739

Tillmann, U., Elbrächter, M., 2010. Plate overlap pattern of Azadinium spinosum Elbrächter et Tillmann (Dinophyceae), the newly discovered primary source of azaspiracid toxins. In: Ho, K.C., Zhou, M.J., Qi, Y.Z. Eds. Proceedings of the 13th International Conference on Harmful Algae. Environmental Publication house, Hong Kong, pp 4244

Tillmann, U., Elbrächter, M., John, U., Krock, B., 2011. A new non-toxic species in the dinoflagellate genus Azadinium: A. poporum sp. nov. Eur. J. Phycol. 46, 74-87

Tillmann, U., Elbrächter, M., Krock, B., John, U., Cembella, A., 2009. Azadinium spinosum gen. et sp. nov. (Dinophyceae) identified as a primary producer of azaspiracid toxins. Eur. J. Phycol. 44, 63-79

Tillmann, U., Elbrächter, M., John, U., Krock, B., Cembella, A., 2010. Azadinium obesum (Dinophyceae), a new nontoxic species in the genus that can produce azaspiracid toxins. Phycologia 49, 169-182

Tillmann, U., Salas, R., Gottschling, M., Krock, B., O’Drisol, D., Elbrächter, M., 2012. Amphidoma languida sp. nov. (Dinophyceae) reveals a close relationship between Amphidoma and Azadinium. Protist 163, 701-719

Töbe, K., Joshi, A.R., Messtorff, P., Tillmann, U., Cembella, A., John, U., submitted. Molecular discrimination of taxa within the dinoflagellate genus Azadinium, the source of azaspiracid toxins. J. Plankton Res. submitted,

Torgersen, T., Bruun Bremmens, N., Rundberget, T., Aune, T., 2008. Structural confirmation and occurence of azaspiracids in Scandinavian brown crabs (Cancer pagurus). Toxicon 51, 93-101

Twiner, M.J., Rehmann, N., Hess, P., Doucette, G.J., 2008. Azaspiracid shellfish poisoning: A review on the chemistry, ecology, and toxicology with emphasis on human health impacts. Mar. Drugs 6, 39-72

Ueoka, R., Ito, A., Izumikawa, M., Maeda, S., Takagi, M., Shin-Ya, K., Yoshida, M., van Soest, R.W.M., Matsunaga, S., 2009. Isolation of azaspiracid-2 from a marine sponge Echinoclathria sp as a potent cytotoxin. Toxicon 53, 680-684 
Tab. 1: Estimated genetic distances (P-values) between species of Amphidomataceae, based on combined ITS region sequences.

\begin{tabular}{|c|c|c|c|c|c|c|c|c|c|}
\hline Species & strain $\mathrm{nr}$ & $<\frac{\tilde{E}}{\frac{5}{5}}$ & < & 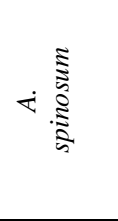 & 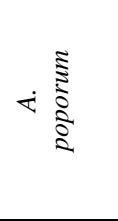 & 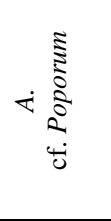 & 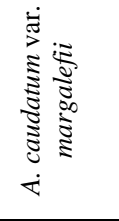 & 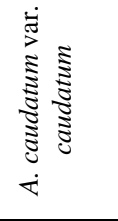 & 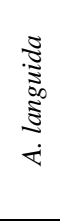 \\
\hline $\begin{array}{l}\text { Azadinium } \\
\text { polongum }\end{array}$ & SHETB2 & & & & & & & & \\
\hline $\begin{array}{c}\text { Azadinium } \\
\text { obesum }\end{array}$ & 2E10 & 0.180 & & & & & & & \\
\hline $\begin{array}{l}\text { Azadinium } \\
\text { spinosum }\end{array}$ & SHETF6 & 0.187 & 0.075 & & & & & & \\
\hline $\begin{array}{c}\text { Azadinium } \\
\text { poporum }\end{array}$ & UTHC5 & 0.184 & 0.052 & 0.101 & & & & & \\
\hline $\begin{array}{l}\text { Azadinium cf. } \\
\text { poporum }\end{array}$ & HI2011 & 0.185 & 0.057 & 0.105 & 0.023 & & & & \\
\hline $\begin{array}{l}\text { Azadiniumcaudatum } \\
\text { var. margalefii }\end{array}$ & IFR1140 & 0.243 & 0.172 & 0.201 & 0.189 & 0.189 & & & \\
\hline $\begin{array}{l}\text { Azadiniumcaudatum } \\
\text { var. caudatum }\end{array}$ & $\begin{array}{c}\text { IFR10- } \\
330\end{array}$ & 0.247 & 0.180 & 0.201 & 0.191 & 0.193 & 0.025 & & \\
\hline $\begin{array}{c}\text { Amphidoma } \\
\text { languida }\end{array}$ & SM1 & 0.323 & 0.321 & 0.321 & 0.315 & 0.315 & 0.323 & 0.325 & \\
\hline
\end{tabular}


Figure legend

Fig. 1: Azadinium spinosum SHETF6, LM (A) and SEM (B-E). (A) Formalin fixed cell showing the antapical spine and one large pyrenoid (arrow). (B, C) Whole cell ventral view, with plate labels. (D) Plate pattern apical view and (E) plate pattern in antapical view. Scale bars $=2 \mu \mathrm{m}$

Fig. 2: Azadinium polongum, LM. (A) Live cell. (B, C) Formalin fixed cell in two focal planes showing the apical pore complex (arrow in B) and the antapical spine (arrow in C). (D) Lugol-fixed cell with large grains of stained material. (E) Formalin fixed cell stained with DAPI as viewed using UV excitation showing the round central nucleus. Scale bars=2 $\mu \mathrm{m}$.

Fig. 3: Azadinium polongum. SEM micrographs of thecae of different cells. (A-B) Ventral view. (C) Dorsal view. (D) Left-lateral view. Scale bars $=2 \mu \mathrm{m}$.

Fig. 4: Azadinium polongum. Diagrammatic illustration of thecal plates. (A) ventral view. (B) Dorsal view. (C) Apical view. (D) Antapical view. Abbreviations: Sa, Sd, Sm, Sp, Ss: sulcal plates as detailed in Fig. 6. Arrowheads in C-D indicate plate overlap pattern.

Fig. 5: Azadinium polongum. SEM micrographs of different cells. (A, B) Apical view showing the whole series of epithecal plates. (C, D) Epitheca in ventral (C) and dorsal (D) view. Scale bars $=2 \mu \mathrm{m}$.

Fig. 6: Azadinium polongum. SEM micrographs of different cells. (A, B) Antapical view of hypothecal plates. (C) Ventral view of cingulum and hypotheca. (D) Apical view of the hypotheca showing the series of cingular plates with an internal view of the sulcal plates (Sa: 
anterior sulcal plate; Sp: posterior sulcal plate; Ss: left sulcal plate; Sm: median sulcal plate; Sd: right sulcal plate). Scale bars $=2 \mu \mathrm{m}$.

Fig. 7: Azadinium polongum. SEM micrographs of different cells. (A-D) Details of the apical pore complex (APC). (A, B) APC in apical view. (C, D) APC viewed from inside the cell. Note that the X-plate in B and D is slightly displaced into the pore plate but still is connected to the 1'plate by a narrow slit. (E) Internal view of APC and apical plates. Note that plate 3' is overlapped by the adjacent apical plates 2'and 4' (arrows). (F) Detailed view of an antapical spine with a cluster of pores emerging from a small bump. (G, H) Detailed external (G) and internal (H) view of the ventral pore located between plates $1^{\prime}$ and $1^{\prime \prime}$. Po = pore plate, $\mathrm{cp}=$ cover plate, $\mathrm{x}=\mathrm{X}$-plate, $\mathrm{vp}=$ ventral pore. Scale bars $=0.5 \mu \mathrm{m}$.

Fig. 8: Azadinium polongum. LM (A-F) and SEM (G-I) of cysts. (A-C) Presumably young cyst in brightfield (A) and in two different focal planes under blue-light-excitation (B, C) showing chlorophyll fluorescence. (D, E) Group of cysts in brightfield (D) and blue-light excitation (E). (G) Cyst with remains of the thecal plates attached. (H-I) Cysts covered by a dense mesh of fibrous material. Scale bars $=2 \mu \mathrm{m}$.

Fig. 9: Scatter plots of morphometric parameters of APC for A. polongum (red squares) and A. spinosum (blue circles). (A) Width versus length of the pore plate (Po). (B) Ratio of width/length versus length of the pore plate (Po). Circles represent 95\% confidence ellipses.

Fig. 10: Maximum likelihood (ML) tree of 33 taxa consisting 15 ingroups and 18 outgroups as inferred from a MAFFT generated alignment covering the complete SSU, complete ITS and the first two domains of the LSU region (907 parsimony informative sites). New strains are indicated in bold. Branch lengths are drawn to scale with a scale bar indicating the number 
of substitutions per site. Numbers on branches are support values (above: ML bootstrap support values, $<60$ not shown; below: Bayesian posterior probabilities, $<0.90$ not shown; maximal support is indicated by an asterisk). Abbreviations: Tho: Thoracosphaeraceae, Gym: Gymnodiniales, Amp: Amphidomataceae, Pro: Prorocentrales, Sue: Suessiales.

Fig. 11: Azadinium spp. SEM micrographs of the apical pore complex APC. (A) A. spinosum. (B) A. obesum. (C) A. poporum. (D) A. polongum. Scale bars $=0.5 \mu \mathrm{m}$. 
Figure legends for supplementary figures

Figure S1: Azadinium polongum. SEM, examples of internal views of different cells used to map plate overlap pattern. (A-B) Internal view of epitheca. Note that plate 2a is overlapped by all adjacent plates (arrow in B). (C-D) Internal view of hypotheca. (E-F) Detailed internal view of epithecal and sulcal plates. Note that both ventral postcingular plates ( $11^{\prime \prime \prime}$ and 6 "' $)$ are overlapped by their adjacent antapical plates (white arrows in E) and that plate Sa overlaps the last cingular plate C6 (black arrows in E and F). Scale bars=2 $\mu \mathrm{m}$.

Figure S2: Azadinium polongum. Variations in plate pattern observed in culture. (A) Unusual shape of the dorsal intercalary plate 2a. (B, C) Unusual shape of the dorsal plates 3' and 2a. Note that in (C) all three intercalary plates are of comparable size. (D) Specimen with just a very narrow connection between plates 3`and 2a. (E) Plate 3’ and 2a completely separated by the intercalary plates 1a and 3a. (F) Plate 2a completely missing. In addition, plate $2^{\prime}$ with an additional suture. (G) Specimen with plate 2a doubled. (H) Plate 1" with additional suture and unusual shape of apical plates. (I) Antapical view, plate 6" with additional suture. (J) Both apical plates 2' and 4' with additional sutures. (K) Unusual shape of apical plates, an extra intercalary plate, and plate 3 " with an extra suture. (L) Antapical view showing the presence of just five postcingular plates. Scale bars $=2 \mu \mathrm{m}$. 


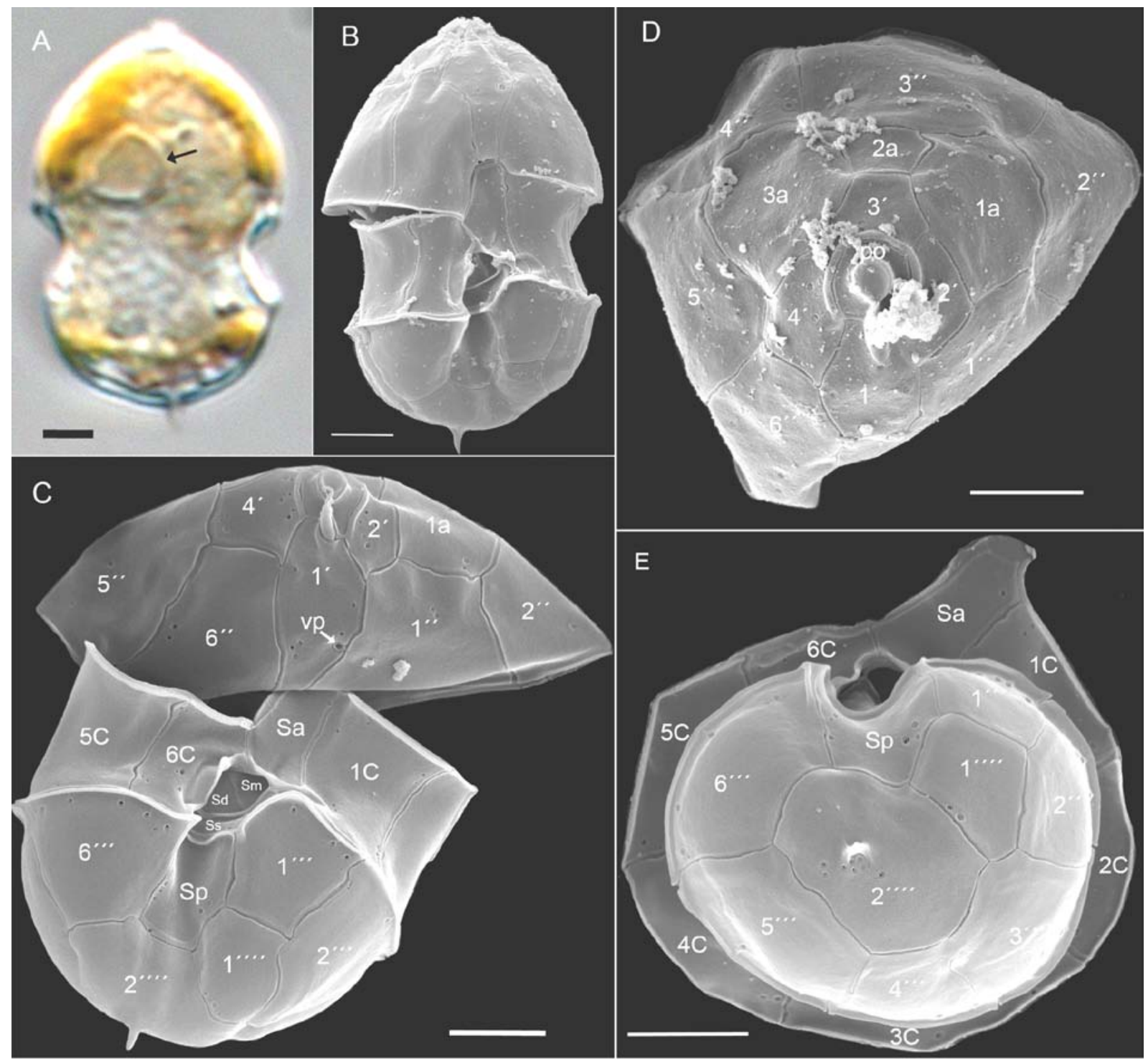

Fig. 1 


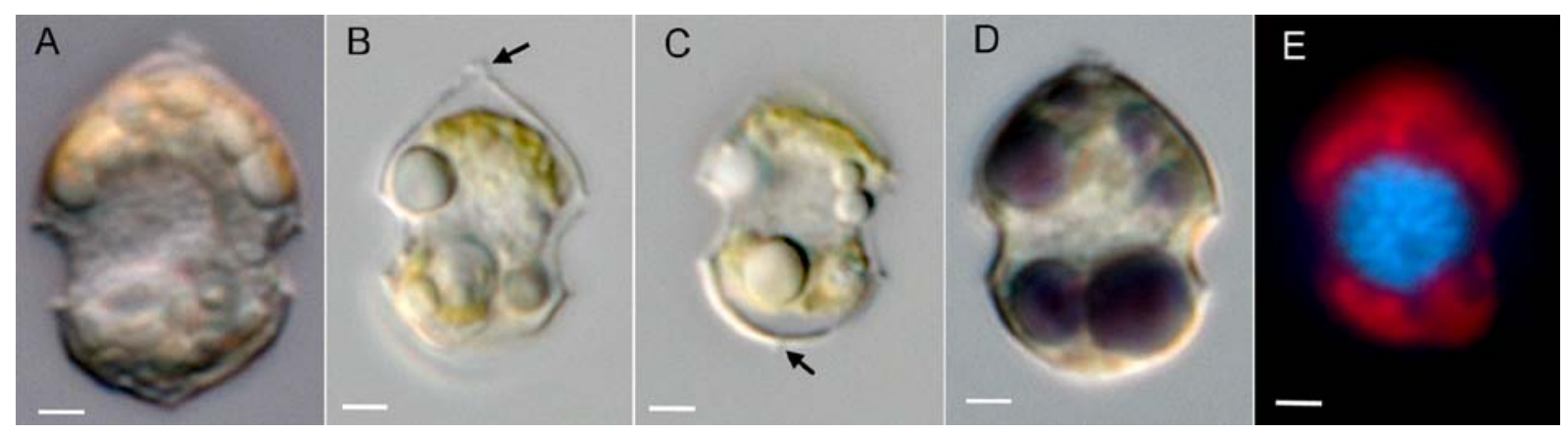

Fig. 2 

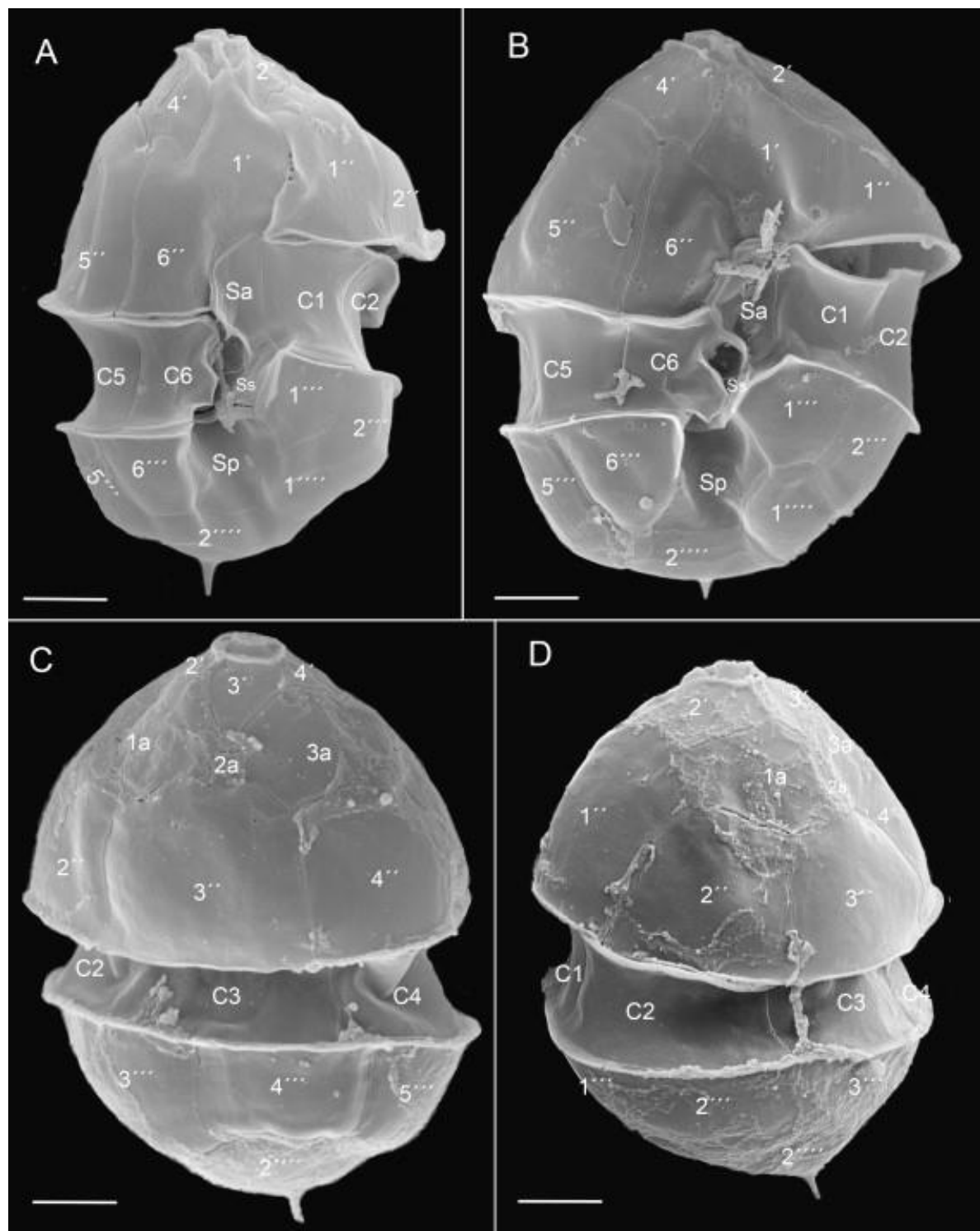

Fig. 3 


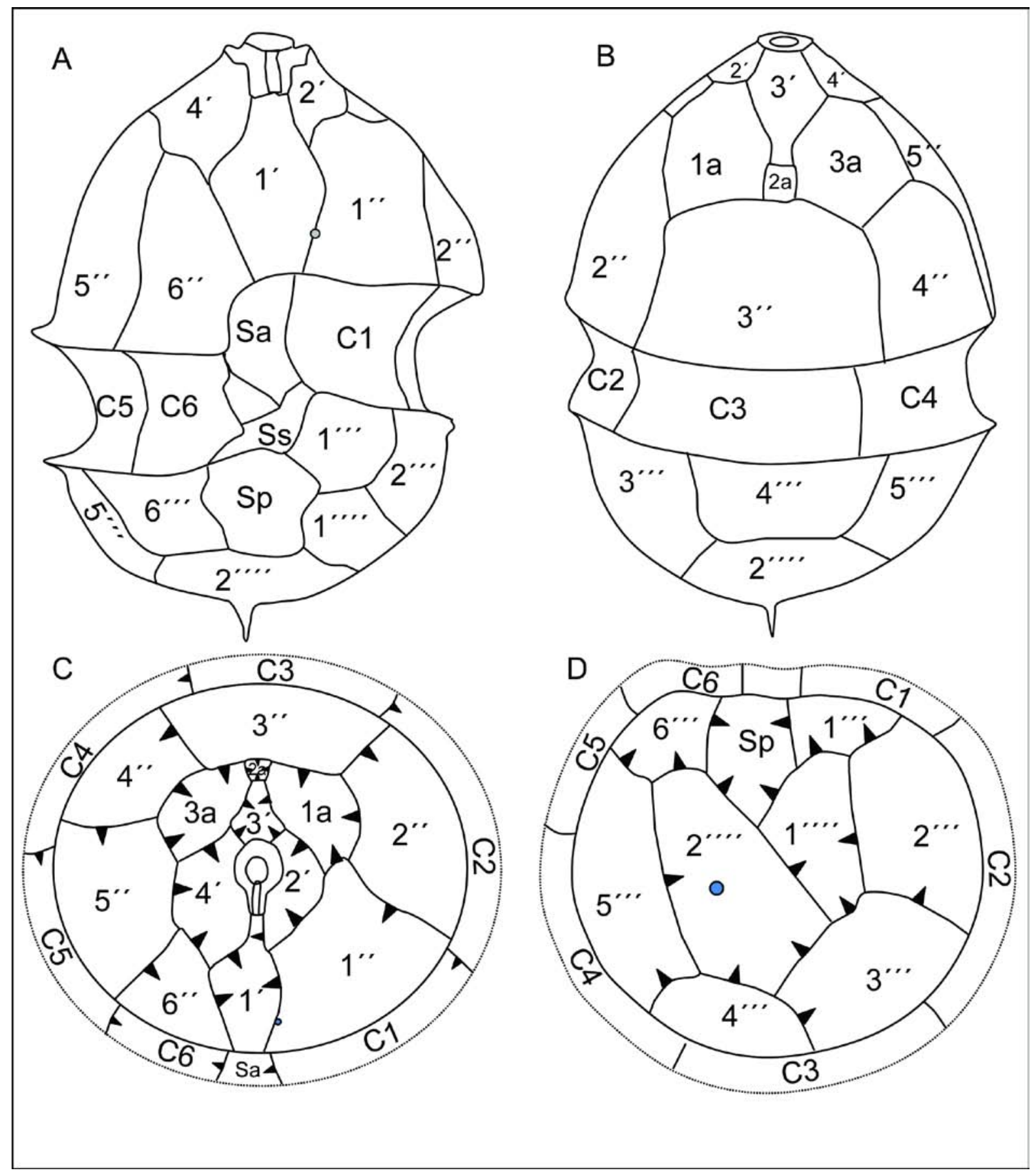

Fig. 4 


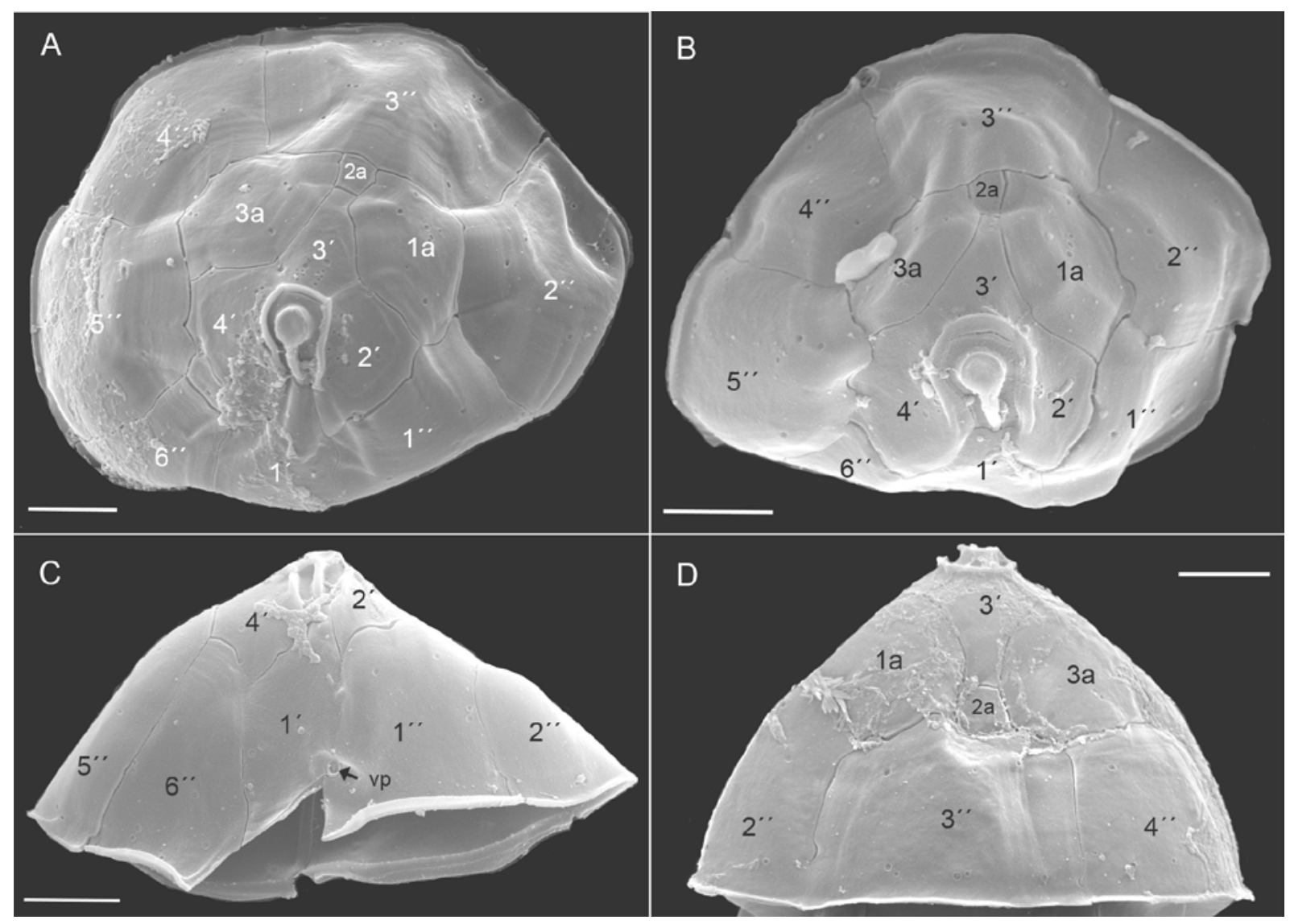

Fig. 5 

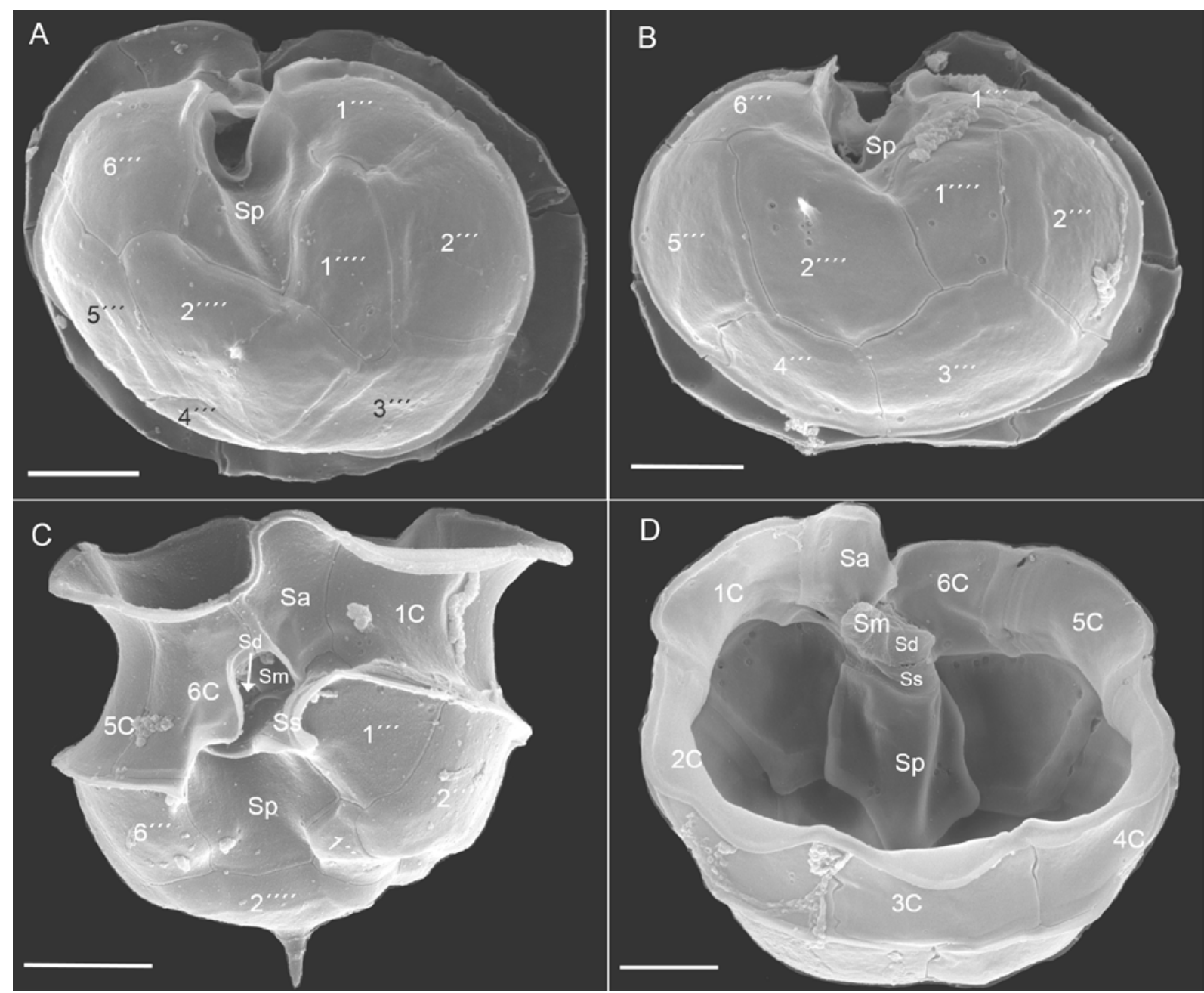

Fig. 6 


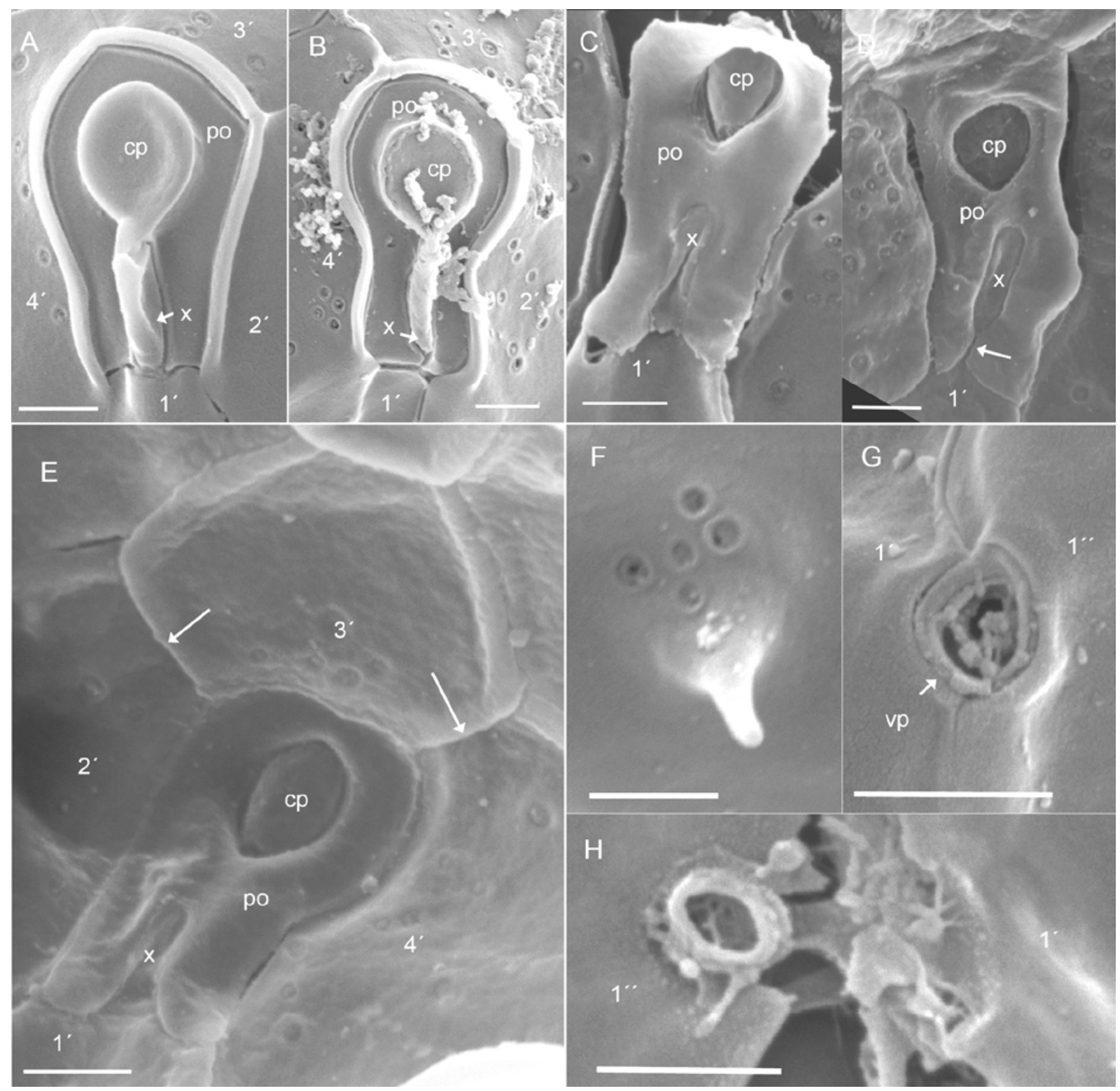

Fig. 7 


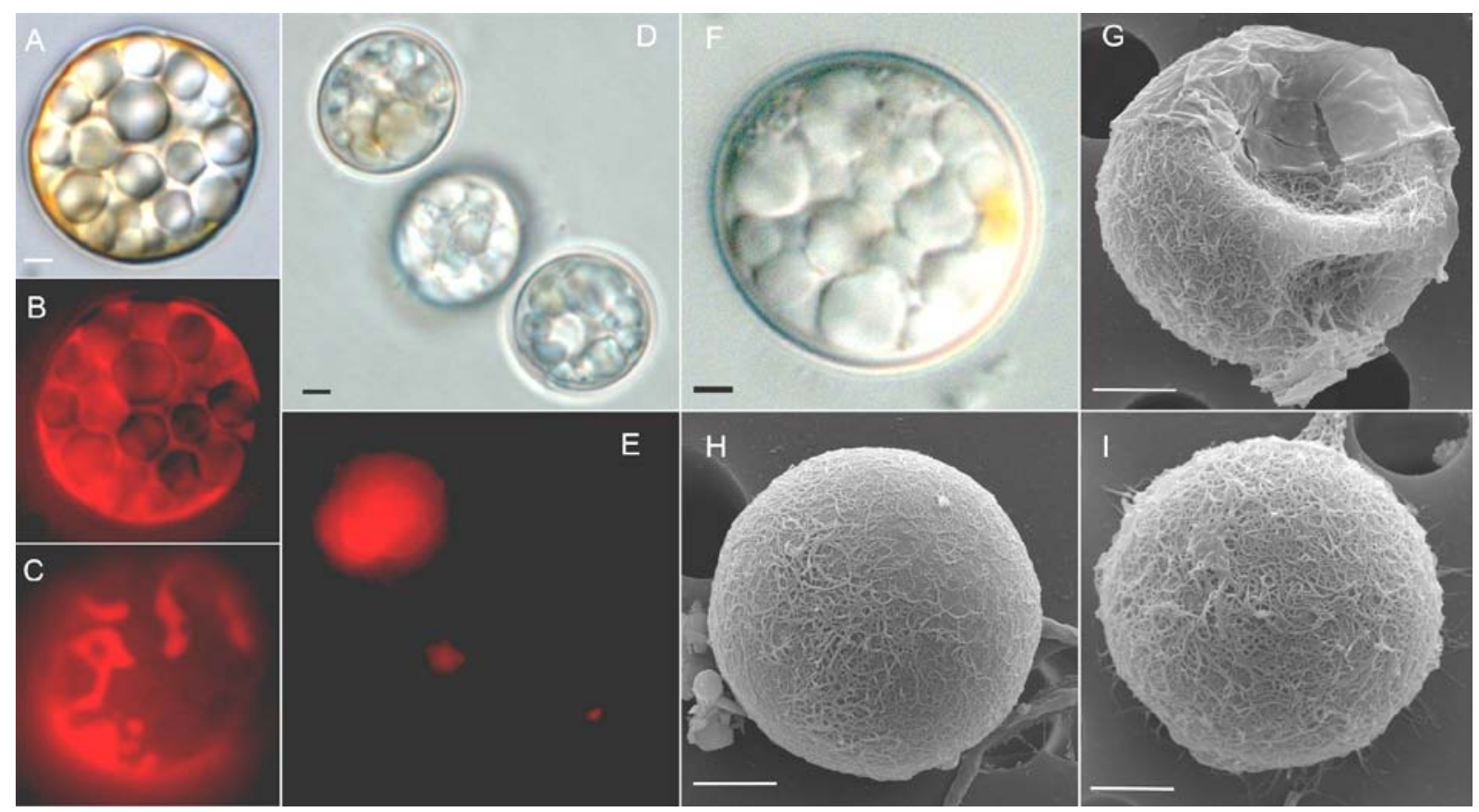

Fig. 8 

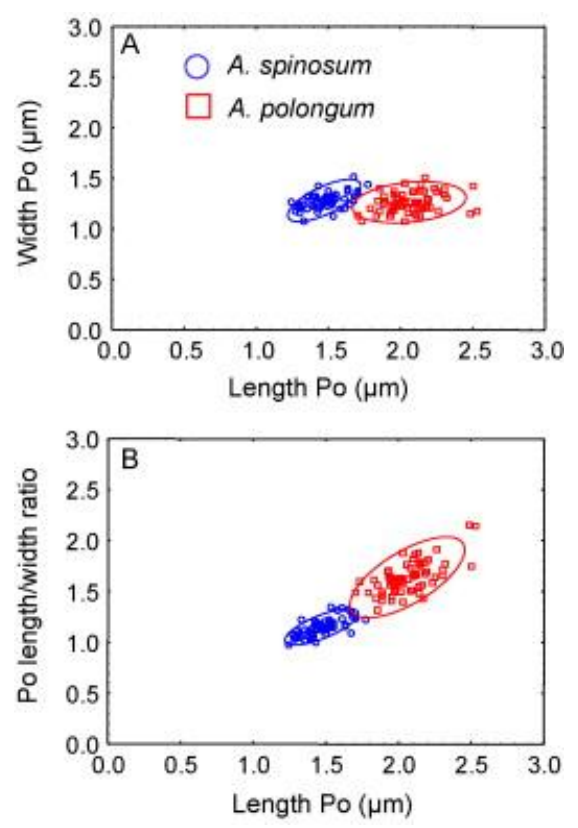

Fig. 9 


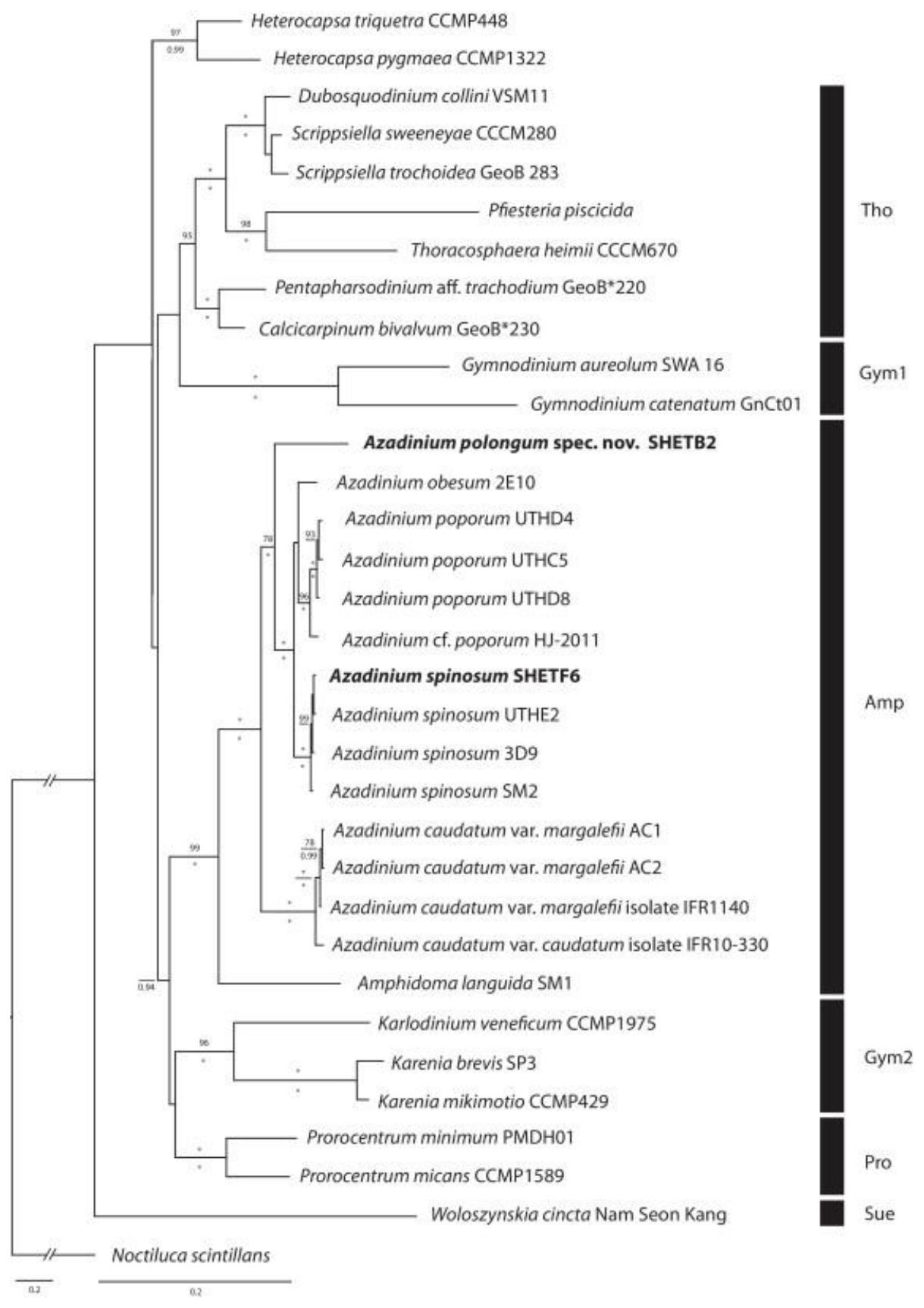

Fig. 10 


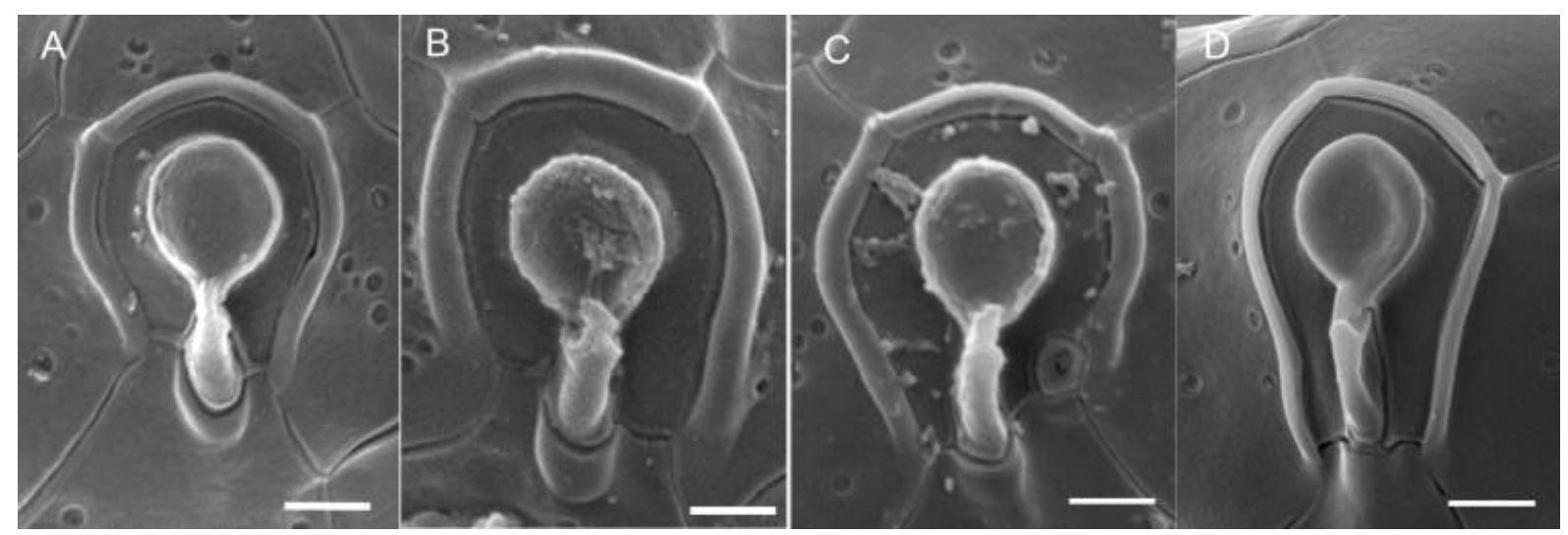

Fig. 11 

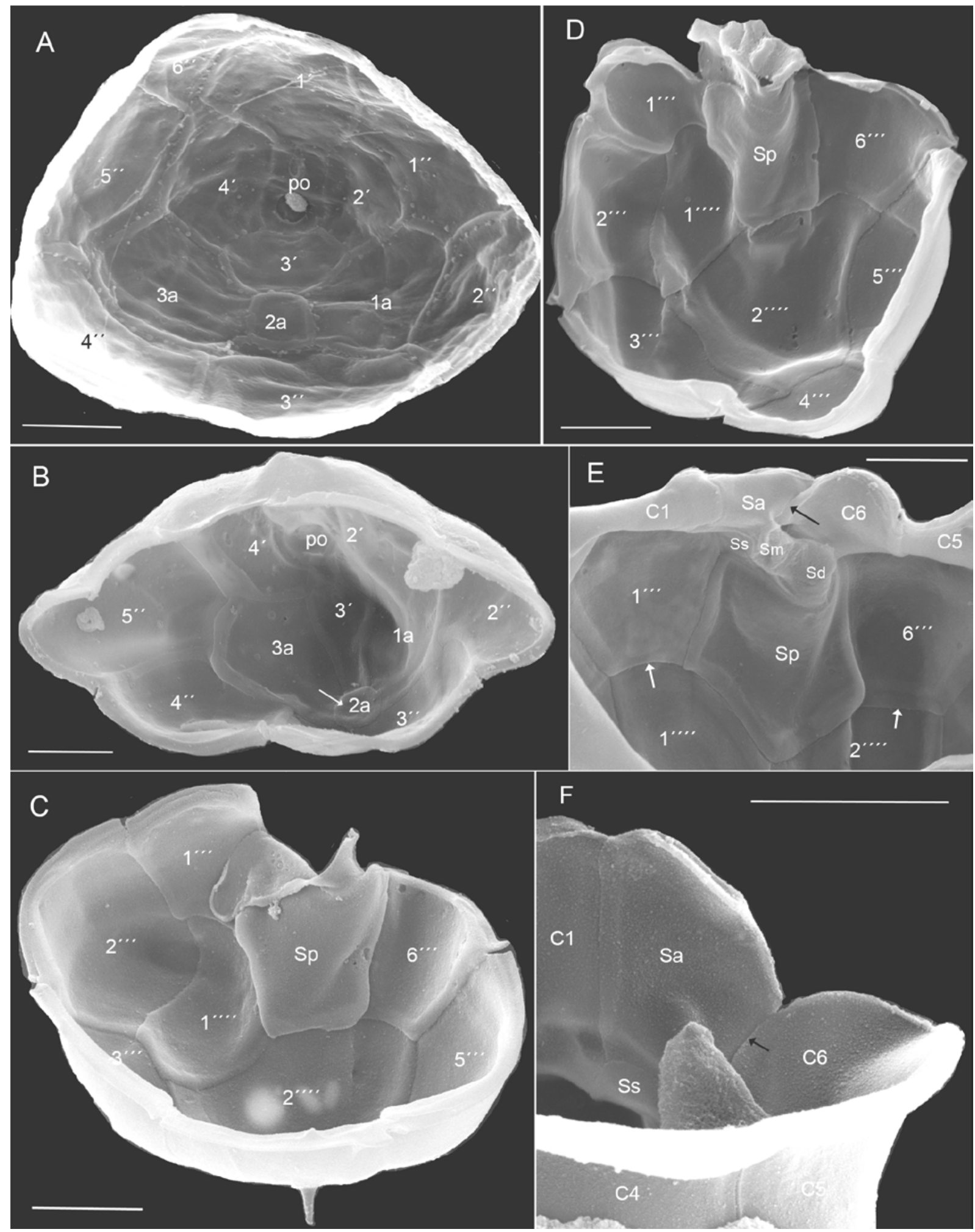

Supplementary Figure S1 

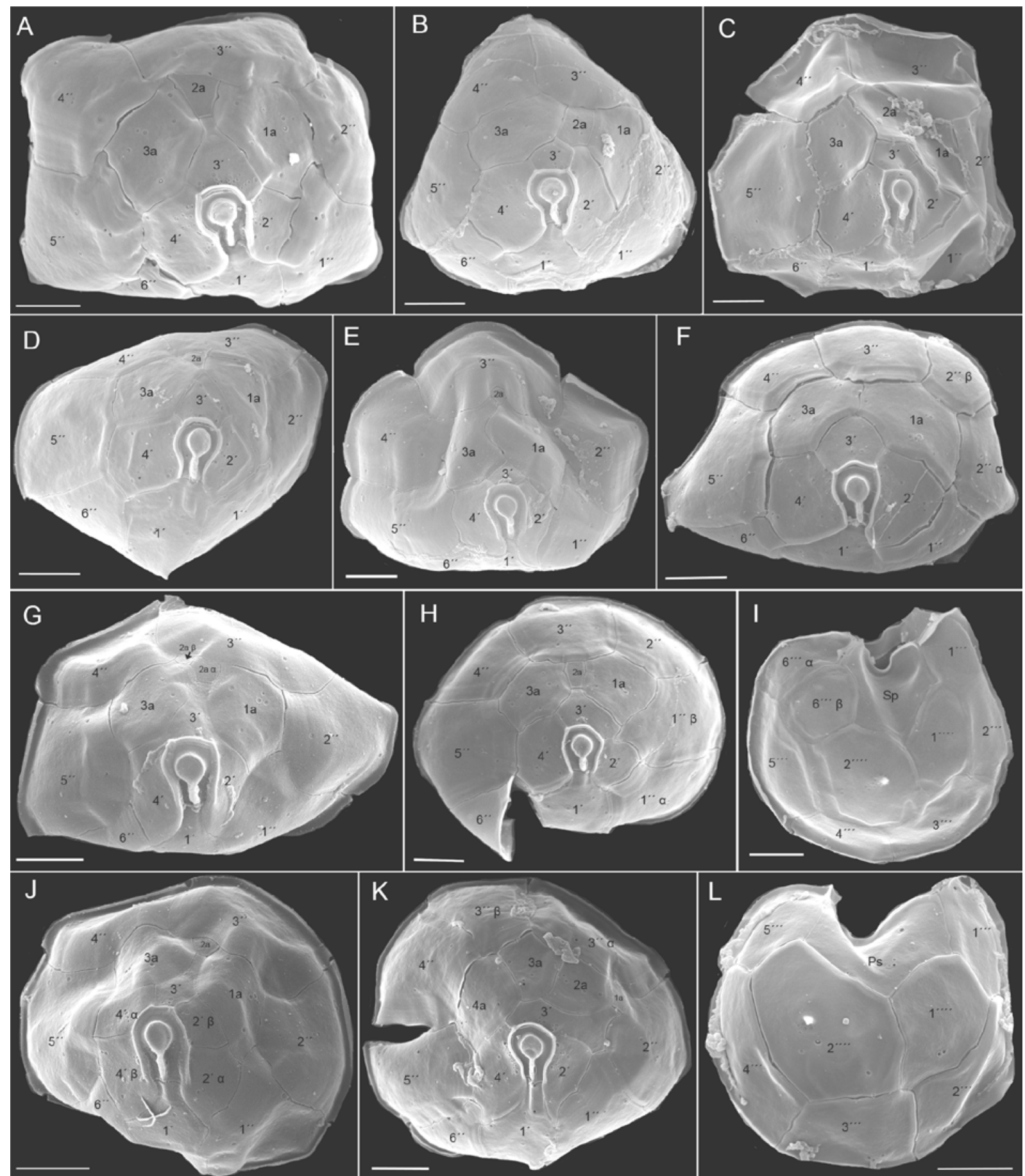

Supplemetary Figure S2 


\section{Supplementary material}

Table S1: Primer list. Abbreviations: fw, forward; rev, reverse.

\begin{tabular}{|c|c|c|c|}
\hline Fragment & primer & sequence $5^{\prime} \rightarrow 3^{\prime}$ & reference \\
\hline \multirow[t]{7}{*}{ SSU } & $1 F(f w)$ & $\begin{array}{l}\text { AAC CTG GTT } \\
\text { GAT CCT GCC } \\
\text { AGT }\end{array}$ & $\begin{array}{l}\text { (Montresor et al., } \\
\text { 2004) }\end{array}$ \\
\hline & 1528R (rev) & $\begin{array}{l}\text { TGA TCC TTC } \\
\text { TGC AGG TTC } \\
\text { ACC TAC }\end{array}$ & $\begin{array}{l}\text { (Montresor et al., } \\
\text { 2004) }\end{array}$ \\
\hline & $528 \mathrm{~F}(\mathrm{fw})$ & $\begin{array}{l}\text { GCG GTA ATT } \\
\text { CCA GCT CCA A }\end{array}$ & $\begin{array}{l}\text { (Montresor et al., } \\
\text { 2004) }\end{array}$ \\
\hline & 1055F (fw) & $\begin{array}{l}\text { GGT GGT GCA } \\
\text { TGG CCG TTC TT }\end{array}$ & $\begin{array}{l}\text { (Montresor et al., } \\
\text { 2004) }\end{array}$ \\
\hline & 536R (rev) & $\begin{array}{l}\text { AAT TAC CGC } \\
\text { GGC KGC TGG } \\
\text { CA }\end{array}$ & $\begin{array}{l}\text { (Montresor et al., } \\
\text { 2004) }\end{array}$ \\
\hline & 1055R (rev) & $\begin{array}{l}\text { ACG GCC ATG } \\
\text { CAC CAC CAC } \\
\text { CCA }\end{array}$ & $\begin{array}{l}\text { (Montresor et al., } \\
\text { 2004) }\end{array}$ \\
\hline & SSU_ITS (fw) & $\begin{array}{l}\text { CAG GTC TGT } \\
\text { GAT GCC CTT }\end{array}$ & $\begin{array}{l}\text { (Gottschling et al., } \\
\text { 2012) }\end{array}$ \\
\hline \multirow[t]{3}{*}{ ITS } & ITS1 (fw) & $\begin{array}{l}\text { GGT GAA CCT } \\
\text { GAG GAA GGA T }\end{array}$ & $\begin{array}{l}\text { (D’Onofrio et al., } \\
1999 \text { ) }\end{array}$ \\
\hline & ITS4 (rev) & $\begin{array}{l}\text { TCC TCC GCT } \\
\text { TAT TGA TAT GC }\end{array}$ & $\begin{array}{l}\text { (D'Onofrio et al., } \\
1999 \text { ) }\end{array}$ \\
\hline & $5,8 \mathrm{~S}(\mathrm{fw})$ & $\begin{array}{l}\text { GTG ATA AGC } \\
\text { ATT GTG AAT } \\
\text { TGC AGR ATT }\end{array}$ & $\begin{array}{l}\text { (Gottschling et al., } \\
\text { 2012) }\end{array}$ \\
\hline \multirow[t]{2}{*}{ LSU } & D1R (fw) & $\begin{array}{l}\text { ACCCGCTGAAT } \\
\text { TTAAGCATA }\end{array}$ & $\begin{array}{l}\text { (Hansen et al., } \\
\text { 2000) }\end{array}$ \\
\hline & D2C (rev) & $\begin{array}{l}\text { CCTTGGTCCGTG } \\
\text { TTTCAAGA }\end{array}$ & $\begin{array}{l}\text { (Hansen et al., } \\
\text { 2000) }\end{array}$ \\
\hline
\end{tabular}


Table S2: Voucherlist. Abbreviations: n.i.: not indicated. Lat.: Latitude. Long.: Longitude

\begin{tabular}{|c|c|c|c|c|c|c|c|}
\hline $\begin{array}{l}\text { Species name with } \\
\text { author }\end{array}$ & Strain No. & Locality & Lat. & Long. & $\begin{array}{l}\text { GenBank } \\
\text { No. 18S } \\
\text { rDNA }\end{array}$ & $\begin{array}{l}\text { GenBank } \\
\text { No. ITS }\end{array}$ & $\begin{array}{l}\text { GenBank } \\
\text { No. 28S } \\
\text { rDNA }\end{array}$ \\
\hline $\begin{array}{l}\text { Amphidoma languida } \\
\text { Tillmann, Salas \& } \\
\text { Elbrächter }\end{array}$ & SM1 & $\begin{array}{l}\text { North Atlantic } \\
\text { (Ireland) }\end{array}$ & $51^{\circ} 39^{\prime} 4.70^{\prime \prime} \mathrm{N}$ & $\begin{array}{l}9^{\circ} 35^{\prime} 11.00^{\prime \prime} \\
W\end{array}$ & JN615412 & JQ247699 & JN615413 \\
\hline $\begin{array}{l}\text { Azadinium caudatum } \\
\text { var. caudatum }\end{array}$ & $\begin{array}{l}\text { M2, isolate } \\
1191,10- \\
330,10-332\end{array}$ & $\begin{array}{l}\text { North Atlantic } \\
\text { (France) }\end{array}$ & $47^{\circ} 49.93^{\prime} \mathrm{N}$ & $03^{\circ} 56.72^{\prime} \mathrm{W}$ & JQ247701 & JQ247700 & JQ247702 \\
\hline $\begin{array}{l}\text { Azadinium caudatum } \\
\text { var. margalefii }\end{array}$ & $\begin{array}{l}\text { M1, isolate } \\
1190,1140, \\
10-20\end{array}$ & $\begin{array}{l}\text { North Atlantic } \\
\text { (France) }\end{array}$ & $47^{\circ} 49.93^{\prime} \mathrm{N}$ & $03^{\circ} 56.72^{\prime} \mathrm{W}$ & JQ247707 & JQ247704 & JQ247708 \\
\hline $\begin{array}{l}\text { Azadinium caudatum } \\
\text { var. margalefii }\end{array}$ & AC1 & $\begin{array}{l}\text { North Sea } \\
\text { (Scotland) }\end{array}$ & $58^{\circ} 38,01^{\prime} \mathrm{N}$ & $03^{\circ} 36,08^{\prime} \mathrm{W}$ & - & JQ247705 & JQ247709 \\
\hline $\begin{array}{l}\text { Azadinium caudatum } \\
\text { var. margalefii }\end{array}$ & AC2 & $\begin{array}{l}\text { North Sea } \\
\text { (Scotland) }\end{array}$ & $58^{\circ} 38,01^{\prime} \mathrm{N}$ & $03^{\circ} 36,08^{\prime} \mathrm{W}$ & - & JQ247706 & - \\
\hline $\begin{array}{l}\text { Azadinium cf. } \\
\text { poporum }\end{array}$ & HJ-2011 & Pacific (Korea) & $37^{\circ} 18^{\prime} \mathrm{N}$ & $126^{\circ} 36^{\prime} \mathrm{E}$ & FR877580 & FR877580 & FR877580 \\
\hline $\begin{array}{l}\text { Azadinium obesum } \\
\text { Tillmann\& Elbrächter }\end{array}$ & 2E10 & $\begin{array}{l}\text { North Sea } \\
\text { (Scotland) }\end{array}$ & $57^{\circ} 3.9^{\prime} \mathrm{N}$ & $2^{\circ} 30.2^{\prime} \mathrm{W}$ & GQ914935 & FJ766093 & GQ914936 \\
\hline $\begin{array}{l}\text { Azadinium polongum } \\
\text { spec. nov. }\end{array}$ & SHETB2 & $\begin{array}{l}\text { Northern North } \\
\text { Sea (Shetland } \\
\text { Islands) }\end{array}$ & $60^{\circ} 12.73^{\prime} \mathrm{N}$ & $0^{\circ} 59.90^{\prime} \mathrm{W}$ & JX559886 & JX559886 & JX559886 \\
\hline $\begin{array}{l}\text { Azadinium poporum } \\
\text { Tillmann \& } \\
\text { Elbrächter }\end{array}$ & UTHD4 & $\begin{array}{l}\text { North Sea } \\
\text { (Danmark) }\end{array}$ & $56^{\circ} 14.52^{\prime} \mathrm{N}$ & $07^{\circ} 27.54^{\prime} \mathrm{E}$ & HQ324899 & HQ324891 & HQ324895 \\
\hline $\begin{array}{l}\text { Azadinium poporum } \\
\text { Tillmann \& } \\
\text { Elbrächter }\end{array}$ & UTHC5 & $\begin{array}{l}\text { North Sea } \\
\text { (Danmark) }\end{array}$ & $56^{\circ} 14.52^{\prime} \mathrm{N}$ & $07^{\circ} 27.54^{\prime} \mathrm{E}$ & HQ324897 & HQ324889 & HQ324893 \\
\hline $\begin{array}{l}\text { Azadinium poporum } \\
\text { Tillmann \& } \\
\text { Elbrächter }\end{array}$ & UTHD8 & $\begin{array}{l}\text { North Sea } \\
\text { (Danmark) }\end{array}$ & $56^{\circ} 14.52^{\prime} \mathrm{N}$ & $07^{\circ} 27.54^{\prime} \mathrm{E}$ & HQ324898 & HQ324890 & HQ324894 \\
\hline $\begin{array}{l}\text { Azadinium spinosum } \\
\text { Elbrächter \& } \\
\text { Tillmann }\end{array}$ & SM2 & $\begin{array}{l}\text { North Atlantic } \\
\text { (Ireland) }\end{array}$ & $51^{\circ} 39^{\prime} 4.70^{\prime \prime N}$ & $\begin{array}{l}9^{\circ} 35^{\prime} 11.00^{\prime \prime} \\
\mathrm{W}\end{array}$ & JN680857 & - & JN165101 \\
\hline $\begin{array}{l}\text { Azadinium spinosum } \\
\text { Elbrächter \& } \\
\text { Tillmann }\end{array}$ & UTHE2 & $\begin{array}{l}\text { North Sea } \\
\text { (Danmark) }\end{array}$ & $56^{\circ} 14.52^{\prime} \mathrm{N}$ & $07^{\circ} 27.54^{\prime} \mathrm{E}$ & HQ324900 & HQ324892 & HQ324896 \\
\hline $\begin{array}{l}\text { Azadinium spinosum } \\
\text { Elbrächter \& } \\
\text { Tillmann }\end{array}$ & 3D9 & $\begin{array}{l}\text { North Sea } \\
\text { (Scotland) }\end{array}$ & $57^{\circ} 3.9^{\prime} \mathrm{N}$ & $2^{\circ} 30.2^{\prime} \mathrm{W}$ & FJ217814 & FJ217816 & FJ217815 \\
\hline $\begin{array}{l}\text { Azadinium spinosum } \\
\text { Elbrächter \& } \\
\text { Tillmann } \\
\end{array}$ & SHETF6 & $\begin{array}{l}\text { Northern North } \\
\text { Sea (Shetland } \\
\text { Islands) }\end{array}$ & $60^{\circ} 12.73^{\prime} \mathrm{N}$ & $0^{\circ} 59.90^{\prime} \mathrm{W}$ & JX559885 & JX559885 & JX559885 \\
\hline $\begin{array}{l}\text { Calcicarpinum } \\
\text { bivalvum } \\
\text { G.Versteegh [= } \\
\text { "Pentapharsodinium } \\
\text { tyrrhenicum" } \\
\text { (Balech)] }\end{array}$ & GeoB*230 & $\begin{array}{l}\text { Mediterranean } \\
\text { Sea (Italy) }\end{array}$ & $40^{\circ} 07^{\prime} \mathrm{W}$ & $17^{\circ} 19^{\prime} \mathrm{E}$ & HQ845329 & HQ845329 & HQ845329 \\
\hline $\begin{array}{l}\text { Duboscquodinium } \\
\text { collini Grassé } \\
\text { [isolated from } \\
\text { Eutintinnus fraknoii } \\
\text { (Daday, 1887)] }\end{array}$ & VSM11 & $\begin{array}{l}\text { Mediterranean } \\
\text { Sea (France) }\end{array}$ & $43^{\circ} 41.10^{\prime} \mathrm{N}$ & $7^{\circ} 18.94^{\prime} \mathrm{E}$ & HM483399 & HM483399 & HM483399 \\
\hline $\begin{array}{l}\text { Gymnodinium } \\
\text { aureolum (Hulburt) } \\
\text { Gert.Hansen }\end{array}$ & SWA 16 & $\begin{array}{l}\text { Atlantic } \\
\text { (Namibia) }\end{array}$ & n.i. & n.i. & AY999082 & AY999082 & AY999082 \\
\hline $\begin{array}{l}\text { Gymnodinium } \\
\text { catenatum } \\
\text { H.W.Graham, } 1943 \\
\end{array}$ & GnCt01 & $\begin{array}{l}\text { East China Sea } \\
\text { (South Korea, } \\
\text { Jinhae Bay) } \\
\end{array}$ & n.i. & n.i. & DQ785882 & DQ785882 & DQ785882 \\
\hline $\begin{array}{l}\text { Heterocapsa } \\
\text { pygmaea A.R.Loebl., } \\
\text { R.J.Schmidt \& } \\
\text { Sherley }\end{array}$ & CCMP1322 & $\begin{array}{l}\text { Atlantic (Gulf of } \\
\text { Mexico) }\end{array}$ & $29^{\circ} 23^{\prime} \mathrm{N}$ & $94^{\circ} 53^{\prime} \mathrm{W}$ & EF492500 & AB084093 & FJ939577 \\
\hline $\begin{array}{l}\text { Heterocapsa triquetra } \\
\text { (Ehrenb., 1840) }\end{array}$ & CCMP448 & $\begin{array}{l}\text { North Atlantic } \\
\text { (USA) }\end{array}$ & $41^{\circ} 32^{\prime} \mathrm{N}$ & $70^{\circ} 37^{\prime} \mathrm{W}$ & GU594638 & AF527816 & EU165307 \\
\hline $\begin{array}{l}\text { Karenia brevis } \\
\text { (C.C.Davis) } \\
\text { G.Hansen \& } \\
\text { Ø.Moestrup }\end{array}$ & SP3 & $\begin{array}{l}\text { Atlantic (Gulf of } \\
\text { Mexico, Texas) }\end{array}$ & n.i. & n.i. & AF352820 & AF352825 & AY355456 \\
\hline
\end{tabular}




\begin{tabular}{|c|c|c|c|c|c|c|c|}
\hline $\begin{array}{l}\text { Karenia mikimotoi } \\
\text { (Miyake \& Komin. ex } \\
\text { M.Oda) Gert.Hansen } \\
\text { \& Moestrup } \\
\end{array}$ & CCMP429 & Atlantic (UK) & $\begin{array}{l}50^{\circ} 21^{\prime} 43.20^{\prime \prime} \\
\mathrm{N}\end{array}$ & $\begin{array}{l}4^{\circ} 10^{\prime} 12.00^{\prime \prime} \\
\mathrm{W}\end{array}$ & FJ587220 & AM184206 & EU165311 \\
\hline $\begin{array}{l}\text { Karlodinium } \\
\text { veneficum } \\
\text { (D.Ballant.) J.Larsen }\end{array}$ & CCMP1975 & $\begin{array}{l}\text { Hyrock Farms } \\
\text { (USA, Maryland) }\end{array}$ & $\begin{array}{l}38^{\circ} 10^{\prime} 23.88^{\prime \prime} \\
\mathrm{N}\end{array}$ & $\begin{array}{l}75^{\circ} 44^{\prime} 14.64 " \\
\text { W }\end{array}$ & EF036540 & EF036540 & EF036540 \\
\hline $\begin{array}{l}\text { Noctiluca scintillans } \\
\text { (Macartney, 1810) }\end{array}$ & n.i. & South China Sea & $\begin{array}{l}22^{\circ} 20^{\prime} 16.31 " \\
\mathrm{~N}\end{array}$ & $\begin{array}{l}114^{\circ} 16^{\prime} 8.24^{\prime \prime} \\
\mathrm{E}\end{array}$ & GQ380592 & GQ380592 & GQ380592 \\
\hline $\begin{array}{l}\text { Pentapharsodinium } \\
\text { aff. trachodium Indel. } \\
\text { \& A.R.Loebl. ( } \equiv \\
\text { Ensiculifera aff. } \\
\text { loeblichii El.R.Cox \& } \\
\text { H.J.Arn.) }\end{array}$ & GeoB*220 & $\begin{array}{l}\text { Atlantic } \\
\text { (Namibia) }\end{array}$ & $30^{\circ} 30^{\prime} \mathrm{S}$ & $13^{\circ} 22^{\prime} \mathrm{E}$ & HQ845328 & HQ845328 & HQ845328 \\
\hline $\begin{array}{l}\text { Pfiesteria piscicida } \\
\text { K.A.Steidinger \& } \\
\text { J.M.Burkholder }\end{array}$ & n.i. & $\begin{array}{l}\text { Chicamacomico } \\
\text { River (USA, } \\
\text { Maryland) }\end{array}$ & n.i. & n.i. & AY112746 & AY112746 & AY112746 \\
\hline $\begin{array}{l}\text { Prorocentrum micans } \\
\text { Ehrenb. }\end{array}$ & CCMP1589 & $\begin{array}{l}\text { North Atlantic } \\
\text { (USA) }\end{array}$ & $41^{\circ} 36^{\prime} \mathrm{N}$ & $71^{\circ} 24^{\prime} \mathrm{W}$ & EU780638 & EU780638 & EU780638 \\
\hline $\begin{array}{l}\text { Prorocentrum } \\
\text { minimum (Pavill.) } \\
\text { J.Schiller }\end{array}$ & PMDH01 & $\begin{array}{l}\text { East China Sea } \\
\text { (Fujian Province) }\end{array}$ & n.i. & n.i. & DQ028763 & DQ054538 & DQ054539 \\
\hline $\begin{array}{l}\text { Scrippsiella } \\
\text { sweeneyae Balech ex } \\
\text { A.R.Loebl. }\end{array}$ & CCCM280 & n.i. & n.i. & n.i. & HQ845331 & HQ845331 & HQ845331 \\
\hline $\begin{array}{l}\text { Scrippsiella } \\
\text { trochoidea (F.Stein) } \\
\text { A.R.Loebl. }\end{array}$ & GeoB 283 & $\begin{array}{l}\text { North Atlantic } \\
\text { (Norway) }\end{array}$ & $63^{\circ} 28^{\prime} \mathrm{N}$ & $9^{\circ} 25^{\prime} \mathrm{E}$ & HQ845330 & HQ845330 & HQ845330 \\
\hline $\begin{array}{l}\text { Thoracosphaera } \\
\text { heimii (Lohmann) } \\
\text { Kamptner }\end{array}$ & CCCM670 & $\begin{array}{l}\text { Atlantic (Gulf of } \\
\text { Mexico) }\end{array}$ & $23^{\circ} 48.9^{\prime} \mathrm{N}$ & $89^{\circ} 45.7^{\prime} \mathrm{W}$ & HQ845327 & HQ845327 & HQ845327 \\
\hline $\begin{array}{l}\text { Woloszynskia cincta } \\
\text { Siano, Montresor \& } \\
\text { Zingone }\end{array}$ & $\begin{array}{l}\text { Nam Seon } \\
\text { Kang }\end{array}$ & Pacific (Korea) & $37^{\circ} 18^{\prime} \mathrm{N}$ & $126^{\circ} 36^{\prime} \mathrm{E}$ & FR690459 & FR690459 & FR690459 \\
\hline
\end{tabular}

\section{References:}

D’Onofrio, G., Marino, D., Bianco, L., Busico, E., Montresor, M., 1999. Towards an assessment on the taxonomy of dinoflagellates that produce calcareous cysts (Calcodinelloideae): a morphological and molecular approach. J. Phycol. 35, 10631078

Gottschling, M., Soehner, S., Zinssmeiste, C., John, U., Plötner, J., Schweikert, M., Aligizaki, K., Elbrächter, M., 2012. Delimitation of the Thoracosphaeraceae (Dinophyceae), including the calcareous dinoflagellates, based on large amounts of ribosomal RNA sequence data. Protist 163, 15-24

Hansen, G., Daugbjerg, N., Henriksen, P., 2000. Comparative study of Gymnodinium mikimotoi and Gymnodinium aureolum, comb.nov. (= Gyrodinium aureolum) based on morphology, pigment composition, and molecular data. J. Phycol. 36, 394-410

Montresor, M., John, U., Beran, A., Medlin, L.K., 2004. Alexandrium tamutum sp. nov. (Dinophyceae): a new nontoxic species in the genus Alexandrium. J. Phycol. 40, 398411 